RELEASED FOR ANNOUNCEMENT

IN NUCLEAR SCIENCE ABSTRACTS
ANL-6894

Metals, Ceramics, and

Materials (TID-4500)

$\mathrm{AEC}$ Research and

Development Report

ARGONNE NATIONAL LABORATORY

9700 South Cass Avenue

CFSTI PRICES

Argonne, Illinois 60439

H.C. $\$ 2.00 ; M N=\ddot{50}$

STUDIES OF STOICHIOMETRIC AND

HYPERSTOICHIOMETRIC SOLID SOLUTION'S

IN THE THORIA-URANIA SYSTEM

by

E. D. Lynch

Metallurgy Division

Final Report - Program 9.5.2

Portions of the material in this report have appeared in the following ANL Metallurgy Division Progress Reports:

$\begin{array}{cc}\text { ANL } & \frac{\text { Page }}{5717} \\ 5837 & 11-12 \\ 5975 & 13-15 \\ 6099 & 24 \\ 6330 & 37-38,99-100 \\ 6516 & 90-93 \\ 6677 & 122-126 \\ & 101-106\end{array}$

December 1965

Operated by The University of Chicago under

Contract W-3l-109-eng-38

with the

U. S. Atomic Energy Commission 


\section{DISCLAIMER}

This report was prepared as an account of work sponsored by an agency of the United States Government. Neither the United States Government nor any agency Thereof, nor any of their employees, makes any warranty, express or implied, or assumes any legal liability or responsibility for the accuracy, completeness, or usefulness of any information, apparatus, product, or process disclosed, or represents that its use would not infringe privately owned rights. Reference herein to any specific commercial product, process, or service by trade name, trademark, manufacturer, or otherwise does not necessarily constitute or imply its endorsement, recommendation, or favoring by the United States Government or any agency thereof. The views and opinions of authors expressed herein do not necessarily state or reflect those of the United States Government or any agency thereof. 


\section{DISCLAIMER}

Portions of this document may be illegible in electronic image products. Images are produced from the best available original document. 

-

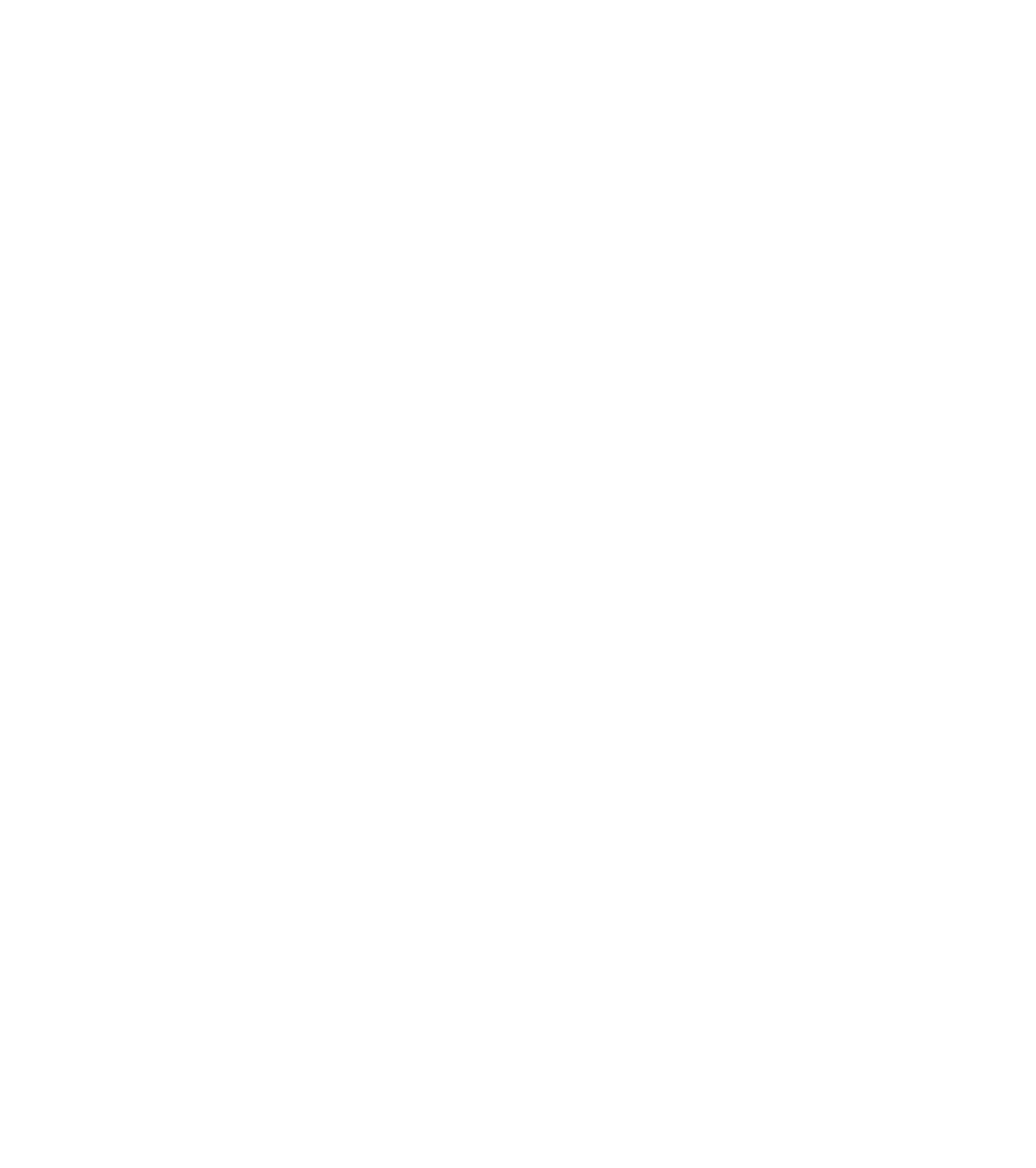


TABLE OF CONTENTS

$\underline{\text { Page }}$

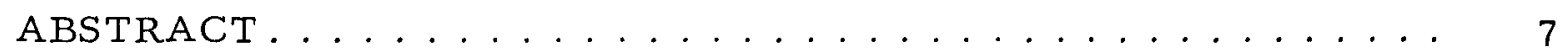

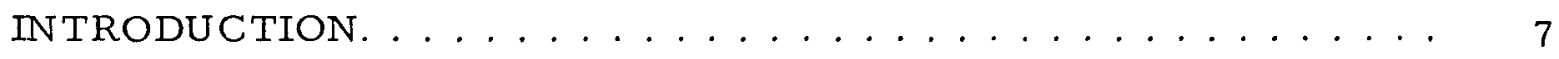

FORMATION OF SOLID SOLUTIONS . . . . . . . . . . . . . . 9

DENSIFICATION BEHAVIOR ................ 16

STOICHIOMETRY OF AIR-SINTERED MATERIALS . . . . . . . 21

STRUCTURAL EFFECTS OF STOICHIOMETRY. . . . . . . . . . 24

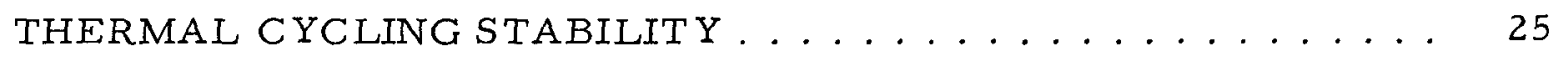

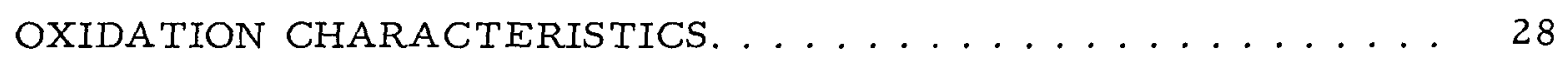

EFFECTS OF STOICHIOMETRY ON DIMENSIONAL STABILITY. . . 30

NEUTRON-DIFFRACTION STUDY. . . . . . . . . 37

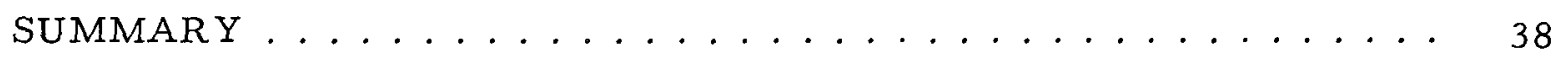

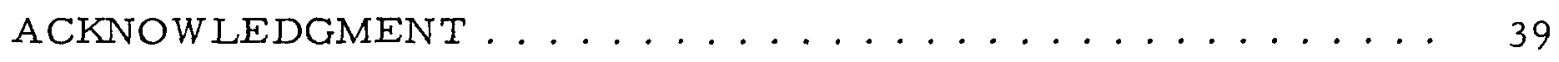

REFERENCES ......................... 40 


\section{LIST OF FIGURES}

$\underline{\text { No. }}$

$\underline{\text { Title }}$

$\underline{\text { Page }}$

1. Shrinkage and Density Changes during Formation of $\mathrm{ThO}_{2}-70.4 \mathrm{~m} / \mathrm{oUO}_{2}$ Solid Solution from $\mathrm{ThO}_{2}-\mathrm{U}_{3} \mathrm{O}_{8} \ldots \ldots$

2. Weight Loss during Formation of a $\mathrm{ThO}_{2}-70.4 \mathrm{~m} / \mathrm{oUO}_{2}$ Solid Solution from $\mathrm{ThO}_{2}-\mathrm{U}_{3} \mathrm{O}_{8} \ldots \ldots \ldots$

3. Effect of Oxygen-Uranium Ratio on Unit-cell Size of $\mathrm{ThO}_{2}-70.4 \mathrm{~m} / \mathrm{oUO}_{2}$ Solid Solution Formed from $\mathrm{ThO}_{2}-\mathrm{U}_{3} \mathrm{O}_{8} \ldots$. .

4. Oxygen Stability during Formation of $\mathrm{ThO}_{2}-70.4 \mathrm{~m} / \mathrm{OUO}_{2}$ Solid Solution from $\mathrm{ThO}_{2}-\mathrm{U}_{3} \mathrm{O}_{8} \ldots \ldots \ldots$. . . . . . . . 13

5. Oxygen Stability of $\mathrm{U}_{3} \mathrm{O}_{8}$ Heated in Air . . . . . . . . . . . 13

6. Thermal Effects Occurring during the Formation of Solid Solutions from $\mathrm{ThO}_{2}-\mathrm{U}_{3} \mathrm{O}_{8}$ Mixtures.............

7. Shrinkage Characteristics of $\mathrm{Air}$-sintered $\mathrm{ThO}_{2}-\mathrm{U}_{3} \mathrm{O}_{8}$ Compositions Parallel to Pressing Direction. . . . . . . . .

8. Shrinkage Characteristics of Hydrogen-sintered $\mathrm{ThO}_{2}-\mathrm{U}_{3} \mathrm{O}_{8}$ Compositions Parallel to Pressing Direction. . . . . . . . . .

9. Shrinkage Characteristics of Hydrogen-sintered $\mathrm{ThO}_{2}-\mathrm{UO}_{2}$ Compositions Perpendicular to Pressing Direction. . . . . . . .

10. Effects of Composition and Heat Treatment on Shrinkage Behavior. . . . . . . . . . . . . . . . . .

11. Effects of Composition and Sintering Temperature on Densification of $\mathrm{ThO}_{2}-\mathrm{U}_{3} \mathrm{O}_{8}$ Compositions Sintered in Air. . . .

12. Effects of Composition and Sintering Temperature on Densification of $\mathrm{ThO}_{2}-\mathrm{U}_{3} \mathrm{O}_{8}$ Compositions Sintered in

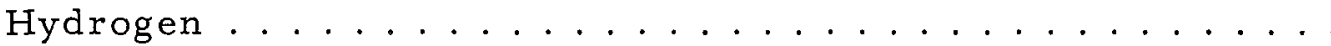

13. Effects of Composition and Sintering Temperature on Densification of $\mathrm{ThO}_{2}-\mathrm{UO}_{2}$ Compositions Sintered in

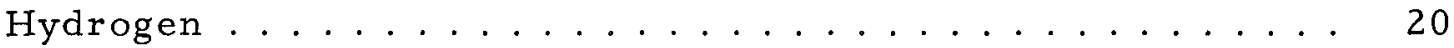

14. Effects of Composition and Heat Treatment on Densification . .

15. Extent of Hyperstoichiometry of Air-sintered $\mathrm{ThO}_{2}-\mathrm{U}_{3} \mathrm{O}_{8}$

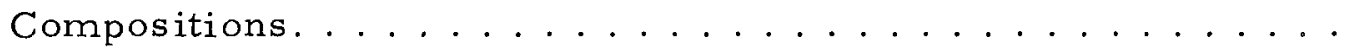

16. Reproducibility of Hyperstoichiometry by Reduction-Oxidation of Solid Solutions Formed from $\mathrm{ThO}_{2}-\mathrm{U}_{3} \mathrm{O}_{8} \ldots \ldots . . . .$.

17. Lattice Parameters for Stoichiometric and Hyperstoichiometric $\mathrm{ThO}_{2}-\mathrm{UO}_{2}$ Solid Solutions............... 


\section{LIST OF FIGURES}

No.

$\underline{\text { Title }}$

$\underline{\text { Page }}$

18. Effect of Thermal Cycling on Oxygen-Uranium Ratio of $\mathrm{ThO}_{2}-70.4 \mathrm{~m} / \mathrm{oUO} \mathrm{O}_{2}$ Formed from $\mathrm{ThO}_{2}-\mathrm{U}_{3} \mathrm{O}_{8}$ at $1450^{\circ} \mathrm{C}$

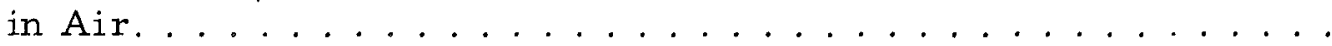

19. Effect of Thermal Cycling on Oxygen-Uranium Ratio of $\mathrm{ThO}_{2}-70.4 \mathrm{~m} / \mathrm{OUO}_{2}$ Formed from Codigested Nitrates . . . . . .

20. Effect of Thermal Cycling on Oxygen-Uranium Ratio of $\mathrm{ThO}_{2}-30.5 \mathrm{~m} / \mathrm{oUO}_{2}$ Solid Solution Formed from Codigested Nitrates at $1450^{\circ} \mathrm{C} \ldots \ldots \ldots \ldots \ldots$

21. Reoxidation Characteristics of Solid Solutions Initially Formed from $\mathrm{ThO}_{2}-\mathrm{U}_{3} \mathrm{O}_{8}$ Sintered in Air at $1200^{\circ} \mathrm{C}$ for

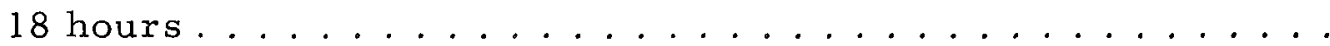

22. Reoxidation Characteristics of $\mathrm{ThO}_{2}-\mathrm{U}_{3} \mathrm{O}_{8}$ Solid Solutions Sintered in Air for 18 hours . . . . . . . . . . . . . .

23. Oxidation Characteristics of Stoichiometric $\mathrm{ThO}_{2}-\mathrm{UO}_{2}$ Solid Solutions Sintered in Hydrogen for 18 hours . . . . . . . . . .

24. Oxidation Peaks (DTA) for Stoichiometric $\mathrm{ThO}_{2}-\mathrm{UO}_{2}$ Solid

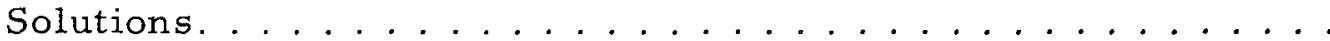

25. Dimensional Stability of a $\mathrm{ThO}_{2}-2.5 \mathrm{~m} / \mathrm{OUO}_{2}$ Solid Solution Heated in Vacuo $\left(10^{-5}\right.$ Torr $)$, Sintered at $1500^{\circ} \mathrm{C} \ldots \ldots \ldots$

26. Dimensional Stability of a $\mathrm{ThO}_{2}-2.5 \mathrm{~m} / \mathrm{oUO}_{2}$ Solid Solution Heated in Vacuo $\left(10^{-5}\right.$ Torr $)$, Sintered at $1650^{\circ} \mathrm{C} \ldots \ldots$.

27. Dimensional Change of a $\mathrm{ThO}_{2}-10 \mathrm{~m} / \mathrm{oUO}_{2}$ Solid Solution Heated in Vacuo $\left(10^{-5}\right.$ Torr $)$, Sintered at $1650^{\circ} \mathrm{C} \ldots \ldots \ldots$

28. Dimensional Stability of a $\mathrm{ThO}_{2}-30 \mathrm{~m} / \mathrm{oUO}_{2}$ Solid Solution Heated in Vacuo $\left(10^{-5}\right.$ Torr $)$, Sintered at $1650^{\circ} \mathrm{C} \ldots \ldots \ldots$

29. Dimensional Stability of a $\mathrm{ThO}_{2}-50 \mathrm{~m} / \mathrm{oUO}_{2}$ Solid Solution Heated in Vacuo $\left(10^{-5}\right.$ Torr $)$, Sintered at $1650^{\circ} \mathrm{C} \ldots \ldots \ldots$

30. Thermal Expansion of Stoichiometric Thoria-Urania Solid Solutions (determined in Vacuo) ............. 34

31. Thermal Expansion of Stoichiometric Thoria-Urania Solid Solutions (determined in air) . ............

32. Thermal Expansion of Hyperstoichiometric Thoria-Urania Solid Solutions (determined in air). . . . . . . . . . . 
No.

I. Sintering Data for $\mathrm{ThO}_{2}-70.4 \mathrm{~m} / \mathrm{oUO}_{2}$ Solid Solution Heated in Air. . . . . . . . . . . . . . . . . . 10

II. X-ray Evaluation of Solid-solution Progress during Sintering of $\mathrm{ThO}_{2}-70.4 \mathrm{~m} / \mathrm{oUO}_{2}$ Mixture in Air . . . . . . 12

III. Oxygen-Uranium Ratios Determined from Constant-weight Measurements in Air .................. 14

IV. Weight Loss for Air-sintered $\mathrm{ThO}_{2}-\mathrm{U}_{3} \mathrm{O}_{8}$ Compositions . . . . 22

V. Ratios of Oxygen to Total Metal for Air-sintered $\mathrm{ThO}_{2}-\mathrm{U}_{3} \mathrm{O}_{8}$

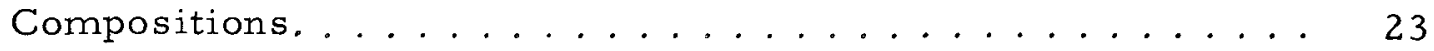

VI. Lattice-parameter Determinations for Solid Solutions Formed from $\mathrm{ThO}_{2}-\mathrm{U}_{3} \mathrm{O}_{8}$ and Treated as Shown. . . . . . . . 24

VII. Oxygen-Uranium Ratios of Air-sintered Solid Solutions Reheated in Air .................... 27

VIII. Calculated Coefficients of Expansion for Thoria-Urania Solid Solutions. . . . . . . . . . . . . . .

IX. Comparison of Calculated and Observed Relative Intensities for $\mathrm{ThO}_{2}-\mathrm{UO}_{2}$ and $\mathrm{ThO}_{2}-\mathrm{U}_{3} \mathrm{O}_{8} \ldots \ldots \ldots$ 


\title{
STUDIES OF STOICHIOMETRIC AND \\ HYPERSTOICHIOMETRIC SOLID SOLUTIONS \\ IN THE THORIA-URANIA SYSTEM
}

by

E. D. Lynch

\begin{abstract}
Studies have been made of the single-phase, solidsolution region of the thoria-urania system, including both stoichiometric and hyperstoichiometric materials.

The temperature range for formation of hyperstoichiometric solid solutions has been determined and related to the decomposition of $\mathrm{U}_{3} \mathrm{O}_{8}$ th rough oxygen loss. The degree of nonstoichiometry has been shown to be reproducible for any given composition and heat treatment. Changes in X-ray lattice parameters, due to stoichiometry, have been determined.

The stability of thoria-urania solid solutions was investigated by study of the oxidation characteristics and thermal-expansion analysis. The reduction of hyperstoichiometric materials to stoichiometry was accompanied by permanent dimensional changes that are related to oxygen loss.
\end{abstract}

\section{INTRODUCTION}

Solid solutions in the thoria-urania system are readily formed by heat treatment of mixtures of the oxides or materials that may be converted to oxides by decomposition or oxidation. From a materials preparation standpoint, there are essentially two procedures in common usage: (1) coprecipitation or codigestion of soluble uranium and thorium salts, principally the nitrates, and (2) intimate mechanical mixing of $\mathrm{UO}_{2}$ or $\mathrm{U}_{3} \mathrm{O}_{8}$ and $\mathrm{ThO}_{2}$. Mixed-nitrate systems yield solid solutions upon decomposition at temperatures as low as $600^{\circ} \mathrm{C}$; mixed-oxide systems require heat treatment above $1000^{\circ} \mathrm{C}$ to promote the solid-solution reaction. Regardless of the initial method of materials preparation, the formation of high-density sintered compacts requires prolonged heating of the solid solutions at temperatures above $1400^{\circ} \mathrm{C}$. 
The reaction to form solid solution may be carried out in air, vacuum, reducing, and inert atmospheres except that dense compacts cannot be formed from $\mathrm{ThO}_{2}-\mathrm{UO}_{2}$ heated in air because of the large volume expansion accompanying the oxidation of $\mathrm{UO}_{2}$ prior to solid solution.

The basic difference in the solid solutions formed by the various sintering treatments is the stoichiometry. The reaction of thoria-urania in a reducing atmosphere or in vacuo results in a complete series of solid solution that is stoichiometric. When the reaction of thoria-urania is carried out in an oxidizing atmosphere, single-phase solid solutions are formed to a maximum of about $75 \mathrm{~m} / \mathrm{OUO}_{2}$, and these solid solutions are not stoichiometric. The stoichiometric solid solutions may be oxidized to varying degrees by heating in air, and the hyperstoichiometric solid solutions may be reduced to a stoichiometry by heat treatment in a reducing atmosphere or in vacuo.

Thorium oxide is an extremely stable material and the complexity of the thoria-urania system is due primarily to the fact that uranium may exist in different valency states. Which valency or combination of valencies uranium assumes depends, in most cases, on the temperature, pressure, and gaseous species surrounding the material.

The retention of the cubic structure has been shown by Alberman and Anderson ${ }^{1}$ during oxidation to $\mathrm{UO}_{2.29}$ and by Hering and Perio ${ }^{2}$ to $\mathrm{UO}_{2.35}$. Gr $\phi$ nvold ${ }^{3}$ shows that oxides in the range $\mathrm{UO}_{2.0}$ to $\mathrm{UO}_{2.5}$ will, when properly annealed, yield two cubic structures, namely, $\mathrm{UO}_{2}$ and $\mathrm{U}_{4} \mathrm{O}_{9}$. Other observers ${ }^{4}$ have noted that continued oxidation from $\mathrm{UO}_{2.25}$ to $\mathrm{UO}_{2.5}$ causes a tetragonal structure to form. Above $500^{\circ} \mathrm{C}$, the tetragonal structure breaks down, and both $\mathrm{U}_{4} \mathrm{O}_{9}$ (cubic) and $\mathrm{U}_{3} \mathrm{O}_{8}$ (orthorhombic) are formed. ${ }^{5}$ Biltz and Muller ${ }^{6}$ found that as the temperature is increased above $600^{\circ} \mathrm{C}, \mathrm{U}_{3} \mathrm{O}_{8}$ slowly begins to lose oxygen until at $1380^{\circ} \mathrm{C}$ it sharply reduces to $\mathrm{UO}_{2.2}$. Warde and Johnson ${ }^{7}$ state that $\mathrm{U}_{3} \mathrm{O}_{8}$ loses oxygen above $600^{\circ} \mathrm{C}$ in air and is converted to $\mathrm{UO}_{2}$ in the range of 1150 to $1400^{\circ} \mathrm{C}$.

The oxygen concentration in urania is also affected by other cations in solid solution that may occupy near-neighbor lattice sites around the uranium ion. Gruen ${ }^{8}$ has shown that in $\mathrm{ThO}_{2}-\mathrm{UO}_{2}$ solid solutions the substitution of $\mathrm{Th}^{4+}$ for uranium ions decreases the amount of electron exchange that might take place around a cation vacancy. In a $\mathrm{ThO}_{2}-\mathrm{UO}_{2}$ solid solution, the net effect of $\mathrm{Th}^{4+}$ substitution would be to inhibit any increase in oxygen-uranium ratio above 2.0 and, in doing this, to restrict any changes in the original cubic lattice. Anderson et al. ${ }^{9}$ have observed this stabilizing influence experimentally, as have Hund and Niessen. ${ }^{10}$ Anderson et al. stated that as little as $22 \mathrm{~m} / \mathrm{o} \mathrm{ThO}_{2}$ stabilized the $\mathrm{UO}_{2}$ cubic structure in air at temperatures up to $1400^{\circ} \mathrm{C}$. Hund and Niessen observed that at least $43.5 \mathrm{~m} / \mathrm{o}$ was necessary to stabilize the structure. Anderson and his 
co-workers also studied the total metal-oxygen ratio in $\mathrm{ThO}_{2}-\mathrm{UO}_{2}$ solid solutions of the type $\mathrm{MO}_{2+\mathrm{y}}$ as a function of temperature, oxygen pressure, and $\mathrm{ThO}_{2}$ concentration. Within the limits of composition necessary to retain a fluorite structure in a $\mathrm{ThO}_{2}-\mathrm{UO}_{2}$ solid solution of the $\mathrm{MO}_{2}+\mathrm{y}$ type, a maximum metal-oxygen ratio of 2.34 occurs at $570^{\circ} \mathrm{C}$ when the mixed oxide is in oxygen at a pressure of 5 to $15 \mathrm{~cm}$ of mercury. ${ }^{9}$ Under such extreme pressures as $120 \mathrm{~atm}$ of oxygen, the fluorite structure broke down in compositions containing over $68 \mathrm{~m} / \mathrm{O} \mathrm{UO}_{2}$.

Variations in stoichiometry of thoria-urania solid solutions are to be expected during preparation and in use, and may result in property changes. The purpose of the work covered in this report was to evaluate the stoichiometry for the single-phase solid-solution region of these materials and to compare the behavior of stoichiometric and hyperstoichiometric solid solutions in various experimental environments.

\section{FORMATION OF SOLID SOLUTIONS}

Solid solutions of thoria-urania were prepared by Hund and Niessen ${ }^{10}$ from water solutions of uranium and thorium nitrates. The solutions were slowly evaporated to dryness and the residue calcined at $1200^{\circ} \mathrm{C}$. Using the nitrates as starting materials, Trzebiatowski and Selwood ${ }^{11}$ precipitated the solid solutions by introducing aliquot solutions into excess ammonia. Lambertson et al. ${ }^{12}$ formed the $\mathrm{ThO}_{2}-\mathrm{UO}_{2}$ solid solutions by heating intimate mixtures of $\mathrm{UO}_{2}$ and $\mathrm{ThO}_{2}$ in hydrogen or in vacuo at temperatures above $1700^{\circ} \mathrm{C}$. A variation of this procedure was reported by Handwerk et al. ${ }^{13}$ in which thoria-urania solid solutions were formed by heating intimate mixtures of $\mathrm{ThO}_{2}-\mathrm{U}_{3} \mathrm{O}_{8}$ in air.

Materials prepared by either the coprecipitation or codigestion technique yield solid solution following decomposition-calcination at temperatures as low as $600^{\circ} \mathrm{C}$. The oxide reactions are solid-state reactions requiring higher temperatures and prolonged times. In the case of $\mathrm{ThO}_{2}$ $\mathrm{U}_{3} \mathrm{O}_{8}$ reaction, there is a low-temperature decomposition (oxygen loss), which may influence solid-solution formation.

A study was made to determine the changes occurring in physical properties and structure of a hyperstoichiometric solid-solution composition during the reaction-sintering process. The composition selected was $\mathrm{ThO}_{2}-70.4 \mathrm{~m} / \mathrm{OUO}_{2}$ (added as $\mathrm{U}_{3} \mathrm{O}_{8}$ ). This composition was used since it was desired to have a high $\mathrm{U}_{3} \mathrm{O}_{8}$ content, and previous experience had shown that this composition approximated the maximum $\mathrm{UO}_{2}$ content that would form a stable solid solution from $\mathrm{ThO}_{2}-\mathrm{U}_{3} \mathrm{O}_{8}$ reacted in air.

During reaction-sintering, changes would be expected to occur in the density, stoichiometry, and lattice parameters of the composition. For 
use in evaluation of these changes, samples were prepared from $\mathrm{ThO}_{2}-\mathrm{U}_{3} \mathrm{O}_{8}$ as follows: Both materials were calcined at $1000^{\circ} \mathrm{C}$ to remove volatiles and to insure complete oxidation of the $\mathrm{U}_{3} \mathrm{O}_{8}$. After calcination, the materials were ball-milled and fabricated into cylindrical shapes by dry-pressing. No binders or lubricants were used since weight-loss during reaction was to be determined.

Samples were heated in air to constant weight at a series of temperatures between 250 and $1350^{\circ} \mathrm{C}$. Constant weight was determined by continuous measurement of the sample weight during heating. After reaching constant weight at any one temperature, samples were cooled in air, and shrinkage and density were measured. X-ray diffraction patterns were made to determine composition and lattice parameters. The stoichiometry of each sample was determined from weight loss during heating and checked by calculation from the weight loss when the sample was reduced to stoichiometric $\mathrm{ThO}_{2}-\mathrm{UO}_{2}$ in hydrogen at $950^{\circ} \mathrm{C}$.

The progress of densification during heating was determined from shrinkage and density measurements as shown in Table I and Fig. 1. There was no dimensional change in samples heated to $600^{\circ} \mathrm{C}$. A slight shrinkage $(1.3 \mathrm{v} / \mathrm{o})$ occurred at $800^{\circ} \mathrm{C}$, and this was followed by an expansion of the samples at 1000 and $1200^{\circ} \mathrm{C}$. The maximum expansion was $4.9 \mathrm{v} / 0$ at $1000^{\circ} \mathrm{C}$, and the expansion decreased to $1.4 \mathrm{v} / \mathrm{o}$ at $1200^{\circ} \mathrm{C}$. Above $1200^{\circ} \mathrm{C}$, shrinkage occurred rapidly, reaching a value of $38.1 \mathrm{v} / 0$ at the maximum sintering temperature of $1350^{\circ} \mathrm{C}$.

TABLE I. Sintering Data for $\mathrm{ThO}_{2}-70.4 \mathrm{~m} / \mathrm{oUO}_{2}$ Solid Solution Heated in Air*

\begin{tabular}{|c|c|c|c|c|c|}
\hline \multirow{2}{*}{$\begin{array}{c}\text { Temp, } \\
{ }^{\circ} \mathrm{C}\end{array}$} & $\begin{array}{c}\text { Time } \\
\text { Held at } \\
\text { Temp, } \\
\text { min }\end{array}$ & \multicolumn{3}{|c|}{ Shrinkage, \%** } & $\begin{array}{c}\text { Sintered } \\
\text { Geometric } \\
\text { Density } \\
\text { (Bulk), } \\
\text { g/cc }\end{array}$ \\
\hline 400 & 2590 & 0.0 & 0.0 & 0.0 & 4.56 \\
600 & 4205 & 0.0 & 0.0 & 0.0 & 4.58 \\
800 & 1085 & 0.4 & 0.4 & 1.3 & 4.64 \\
1000 & 1285 & -1.1 & -1.9 & -4.9 & 4.33 \\
1200 & 1390 & 0.5 & -1.0 & -1.4 & 4.49 \\
1250 & 4335 & 3.5 & 2.0 & 7.4 & 4.80 \\
1300 & 4195 & 13.3 & 11.8 & 32.5 & 6.65 \\
1350 & 4290 & 14.3 & 15.8 & 38.1 & 7.19 \\
\hline
\end{tabular}

$* \mathrm{UO}_{2}$ added as $\mathrm{U}_{3} \mathrm{O}_{8}$.

**Negative sign indicates expansion. 


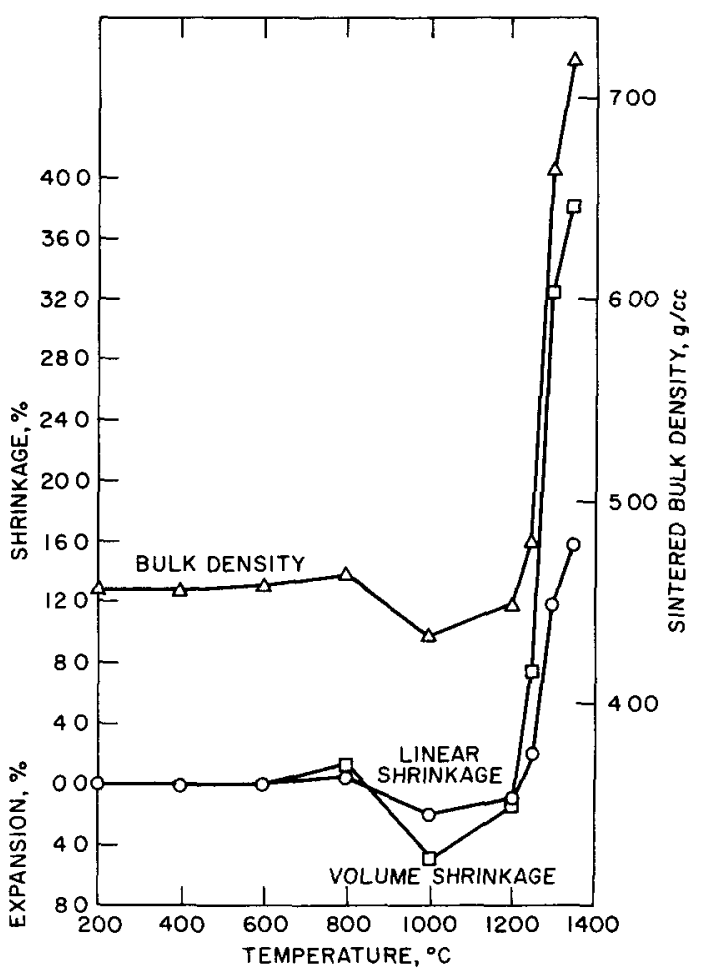

106-4609 Rev. 1

Fig. 1. Shrinkage and Density Changes during Formation of $\mathrm{ThO}_{2}-70.4 \mathrm{~m} / \mathrm{oUO}_{2}$ Solld Solution from $\mathrm{ThO}_{2}-\mathrm{U}_{3} \mathrm{O}_{8}$
Bulk-density changes closely followed the shrinkage curves. Up to $600^{\circ} \mathrm{C}$, the bulk density was approximately the same as the pressed density of the pellets ( $4.57 \mathrm{~g} / \mathrm{cc}$ average). Bulk density increased to $4.64 \mathrm{~g} / \mathrm{cc}$ at $800^{\circ} \mathrm{C}$, followed by a decrease to $4.33 \mathrm{~g} / \mathrm{cc}$ at $1000^{\circ} \mathrm{C}$. Above $1000^{\circ} \mathrm{C}$, the density in creased very rapidly to $7.19 \mathrm{~g} / \mathrm{cc}$ at the maximum sintering temperature of $1350^{\circ} \mathrm{C}$.

The changes in bulk density and shrinkage can be correlated with the oxygen loss from the system as shown in Fig. 2. At temperatures up to $800^{\circ} \mathrm{C}$, oxygen was lost at approximately a linear rate, and some densification occurred at $800^{\circ} \mathrm{C}$. Between $800^{\circ} \mathrm{C}$ and $1000^{\circ} \mathrm{C}$, there was a sharp increase in the rate of loss of oxygen, and the dimensional expansion was thought to be a bloating effect due to the gas release through the pores. Above $1000^{\circ} \mathrm{C}$, the rate of oxygen release increased but

was accompanied by sintering of the solid solution formed, thus resulting in shrinkage of dimensions.

Fig. 2.

Weight Loss during Formation of a $\mathrm{ThO}_{2}-70.4 \mathrm{~m} / \mathrm{oUO}_{2}$ Solid Solution from $\mathrm{ThO}_{2}-\mathrm{U}_{3} \mathrm{O}_{8}$

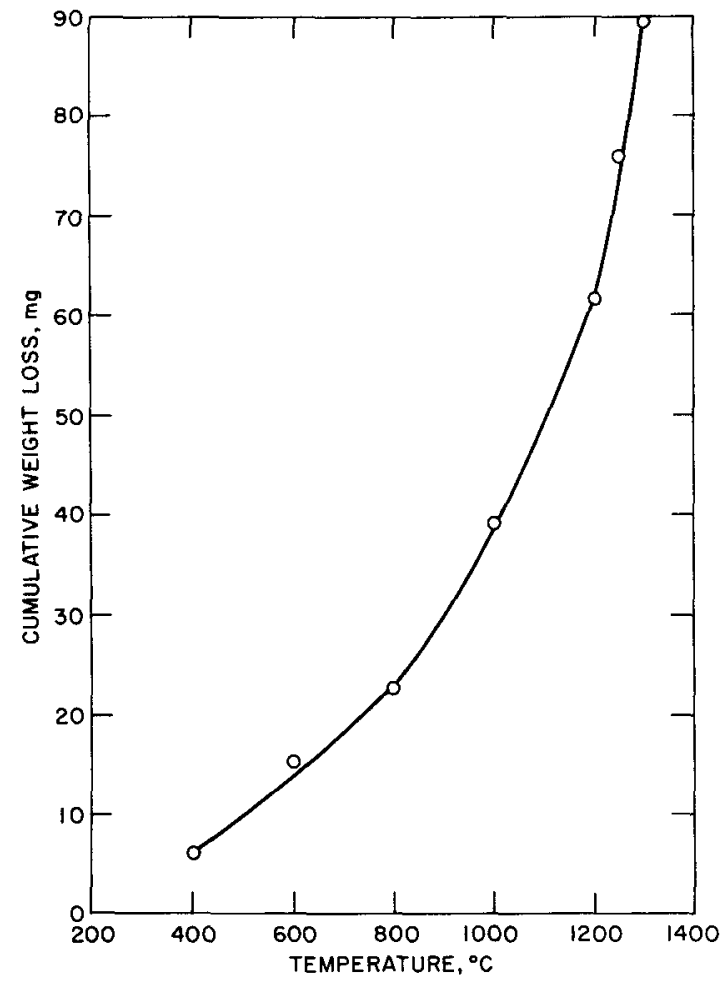


To follow the progress of reaction more closely, $X$-ray diffraction patterns were made of each sample and analyzed for phases present and unit-cell size of the solid-solution phase (Table II).

At temperatures up to $800^{\circ} \mathrm{C}$, the phases present were $\mathrm{U}_{3} \mathrm{O}_{8}$ and $\mathrm{ThO}_{2}$. At $1000^{\circ} \mathrm{C}$, weak lines were present that showed the beginning of the formation of cubic solid solution. At $1200^{\circ} \mathrm{C}$, lines were evident for solid solution and $\mathrm{U}_{3} \mathrm{O}_{8}$ but no distinct lines for $\mathrm{ThO}_{2}$. Above $1250^{\circ} \mathrm{C}$, the only phase present was cubic solid solution. The change in unit-cell size of the solid solution was related to the oxygen content of the solid solution, as shown in Fig. 3. After solid solution had become the major phase $\left(1200^{\circ} \mathrm{C}\right.$ and above), there was a linear relationship between unit-cell size and oxygen-uranium ratio. These data indicate primarily the extent of the reaction between $\mathrm{U}_{3} \mathrm{O}_{8}$ and $\mathrm{ThO}_{2}$ at each sintering temperature. Extrapolation is indicated in Fig. 3 to the unit-cell size of $\mathrm{ThO}_{2}(5.5997 \AA)$ at an oxygen-uranium ratio of 2.67, corresponding to the conditions of the mixtures of $\mathrm{U}_{3} \mathrm{O}_{8}-\mathrm{ThO}_{2}$ before heating.

TABLE II. X-ray Evaluation of Solidsolution Progress during Sintering of

$\mathrm{ThO}_{2}-70.4 \mathrm{~m} / \mathrm{oUO}_{2}$ Mixture in Air*

\begin{tabular}{|c|c|c|}
\hline $\begin{array}{l}\text { Temp, } \\
{ }^{\circ} \mathrm{C}\end{array}$ & $\begin{array}{c}\text { Unit-cell } \\
\text { Size } \\
\AA\end{array}$ & Phases Present \\
\hline 1000 & 5.5004 & $\begin{array}{l}\mathrm{ThO}_{2}, \mathrm{U}_{3} \mathrm{O}_{8} \\
\text { solid solution }\end{array}$ \\
\hline 1200 & 5.4875 & Solid solution, $\mathrm{U}_{3} \mathrm{O}_{8}$ \\
\hline 1250 & 5.4861 & Solid solution, $\mathrm{U}_{3} \mathrm{O}_{8}(?)$ \\
\hline 1300 & 5.4789 & Solid solution \\
\hline 1350 & 5.4770 & Solid solution \\
\hline
\end{tabular}

$* \mathrm{UO}_{2}$ added as $\mathrm{U}_{3} \mathrm{O}_{8}$.

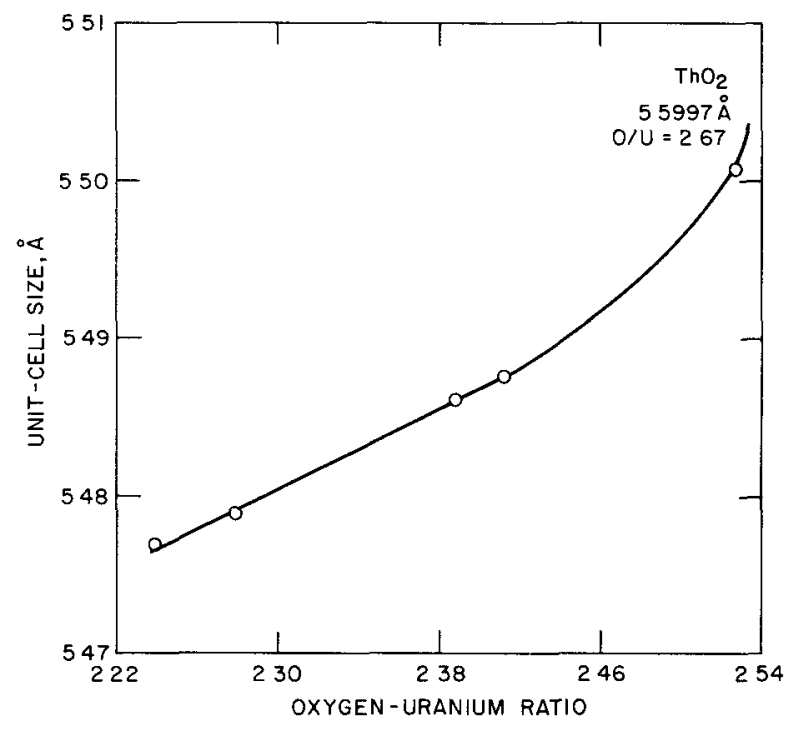

$106-4602$ Rev. 1

Fig. 3. Effect of Oxygen-Uranium Ratio on Unit-cell Size of $\mathrm{ThO}_{2}-70.4 \mathrm{~m} / \mathrm{oUO}_{2}$ Solid Solution Formed from $\mathrm{ThO}_{2}-\mathrm{U}_{3} \mathrm{O}_{8}$

The $\mathrm{X}$-ray study showed that solid solution could begin as low as $1000^{\circ} \mathrm{C}$ and was essentially complete at $1250^{\circ} \mathrm{C}$. From 1250 to $1350^{\circ} \mathrm{C}$, unit-cell size reduced as the oxygen content of the system decreased during completion of the solid-solution reaction and sintering. 


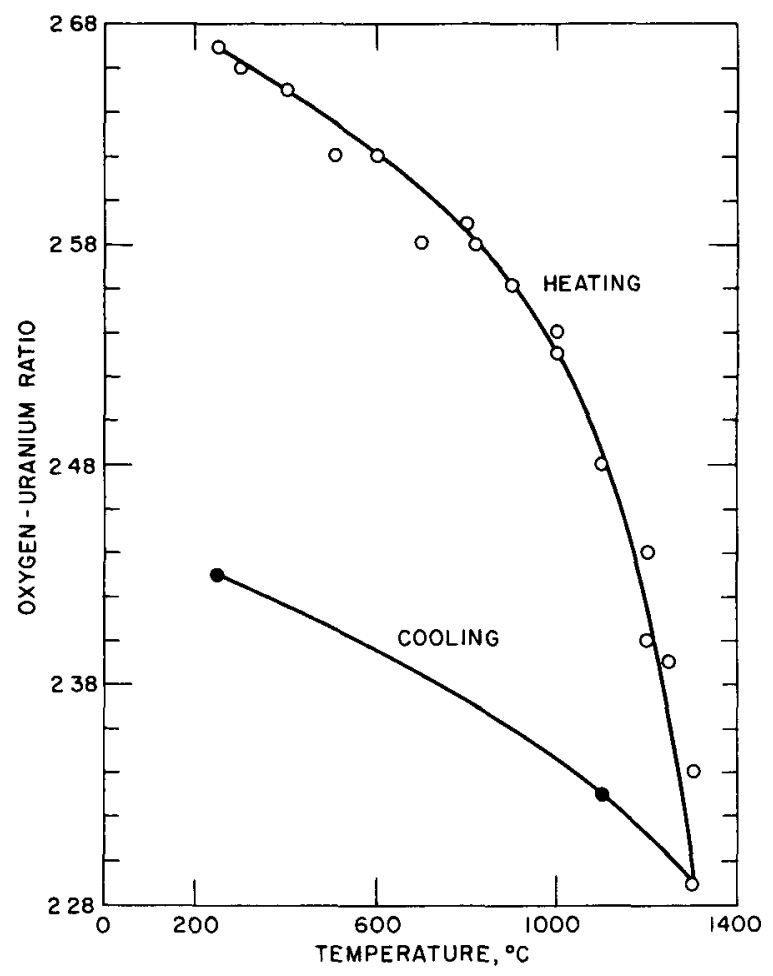

106-4605 Rev. 1

Fig. 4. Oxygen Stability during Formation of $\mathrm{ThO}_{2}-70.4 \mathrm{~m} / \mathrm{oUO}_{2}$ Solid Solution from $\mathrm{ThO}_{2}-\mathrm{U}_{3} \mathrm{O}_{8}$
The oxygen-uranium ratios calculated from equilibrium weightloss measurements during reactionsintering are shown in Fig. 4. As the temperature was increased there was a nearly linear decrease in the oxygen-uranium ratio to $800^{\circ} \mathrm{C}$.

Above the temperature at which solid solution was first evidenced $\left(1000^{\circ} \mathrm{C}\right)$, the curve breaks sharply and reaches an oxygen-uranium ratio of 2.29 at $1350^{\circ} \mathrm{C}$. Upon cooling, the sample showed an oxygen gain, and the $O / U$ value was 2.43 for the sample when removed from the thermogravimetric balance. This corresponds to a solidsolution composition of $\mathrm{U}_{0.7} \mathrm{Th}_{0.3} \mathrm{O}_{2.30}$.

For comparison, a sample of $\mathrm{U}_{3} \mathrm{O}_{8}$ was treated in an identical manner to $1250^{\circ} \mathrm{C}$, the temperature at which solid solution was essentially complete in the $\mathrm{U}_{3} \mathrm{O}_{8}-\mathrm{ThO}_{2}$ mixture. No change was observed in the oxygenuranium ratio of $\mathrm{U}_{3} \mathrm{O}_{8}$ (Fig. 5) up to $400^{\circ} \mathrm{C}$, and the ratio changed slowly

to a value of 2.65 at $800^{\circ} \mathrm{C}$. Above $800^{\circ} \mathrm{C}$, oxygen was lost at an increasingly rapid rate to a value of $\mathrm{O} / \mathrm{U}=2.59$ at $1250^{\circ} \mathrm{C}$. Oxygen was regained on cooling to a value of $O / U=2.65$. The sample was not cooled to equilibrium weight.

Oxygen-uranium ratios obtained on heating $\mathrm{U}_{3} \mathrm{O}_{8}$ alone and mixed with $\mathrm{ThO}_{2}$ are compared in Table III. The loss of oxygen from $\mathrm{U}_{3} \mathrm{O}_{8}$ was accelerated in the presence of thoria and especially in the temperature range of solid-solution formation. Oxygen loss was appreciable for the mixture at temperatures below that at which solid-solution formation could be detected by $X$-ray

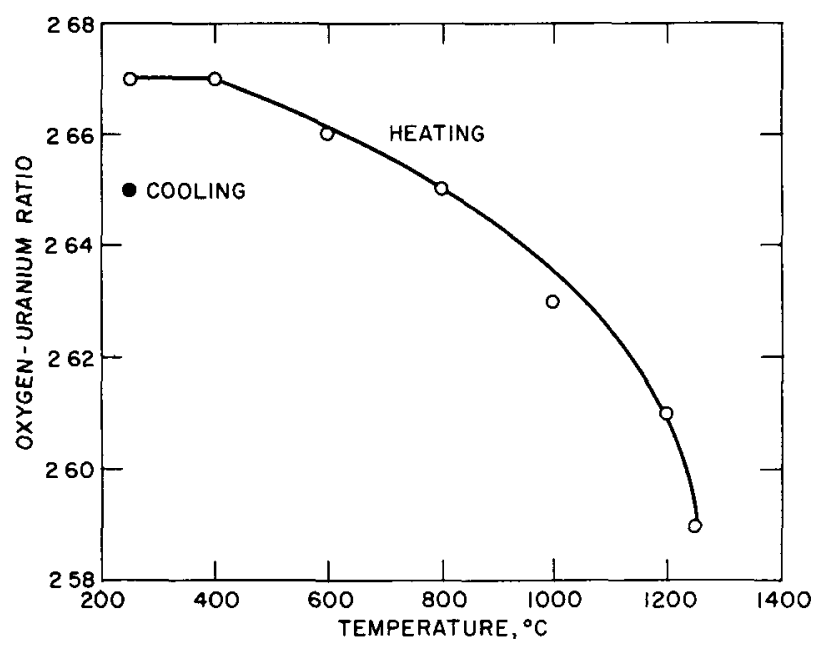

106-4606 Rev. 1

Fig. 5. Oxygen Stability of $\mathrm{U}_{3} \mathrm{O}_{8}$ Heated in Air 
analysis. Apparently the decomposition of the $\mathrm{U}_{3} \mathrm{O}_{8}$ activates the formation of the solid solution, and this, in turn, promotes the decomposition of the $\mathrm{U}_{3} \mathrm{O}_{8}$.

TABLE III. Oxygen-Uranium Ratios Determined from Constant-weight Measurements in Air

\begin{tabular}{|c|c|c|}
\hline \multirow{2}{*}{$\begin{array}{c}\text { Temp, } \\
{ }^{\circ} \mathrm{C}\end{array}$} & \multicolumn{2}{|c|}{ Oxygen-Uranium Ratio } \\
\cline { 2 - 3 } 250 & $\mathrm{U}_{3} \mathrm{O}_{8}$ & $\mathrm{ThO}_{2}-\mathrm{U}_{3} \mathrm{O}_{8}{ }^{*}$ \\
400 & 2.67 & 2.67 \\
600 & 2.67 & 2.65 \\
800 & 2.66 & 2.62 \\
1000 & 2.65 & 2.59 \\
1200 & 2.63 & 2.53 \\
1250 & 2.61 & 2.41 \\
Cooled to 250 & 2.59 & 2.40 \\
\hline
\end{tabular}

*In the ratio $\mathrm{ThO}_{2}-70.4 \mathrm{~m} / \mathrm{oUO}_{2}$.

Differential thermal analysis (DTA) was used as a technique for further study of solid-solution formation of the hyperstoichiometric materials.

The raw materials used were $\mathrm{U}_{3} \mathrm{O}_{8}$ and $\mathrm{ThO}_{2}$ that had been calcined in air at $1200^{\circ} \mathrm{C}$ for $8 \mathrm{hr}$ to remove volatile materials and to insure complete conversion to $\mathrm{U}_{3} \mathrm{O}_{8}$. Mechanical mixtures were made by ball-milling for $5 \mathrm{hr}$. Compositions were prepared in the range of $\mathrm{ThO}_{2}-2.5 \mathrm{~m} / \mathrm{oUO}_{2}$ to $\mathrm{ThO}_{2}-90 \mathrm{~m} / \mathrm{oUO}_{2}$. Fused $\mathrm{ThO}_{2}$ was used as the reference material, and all determinations were made in static air by using a heating rate of $10^{\circ} \mathrm{C} / \mathrm{min}$.

The results of these determinations, together with a thermogram for $\mathrm{U}_{3} \mathrm{O}_{8}$, are shown in Fig. 6. The DTA thermogram for $\mathrm{U}_{3} \mathrm{O}_{8}$ shows three small endothermic peaks at approximately 145,230 , and $310^{\circ} \mathrm{C}$, and a large endothermic peak at $920^{\circ} \mathrm{C}$. The large endothermic peak occurs where the rapid change in $\mathrm{O} / \mathrm{U}$ ratio, during heating, occurred and is associated with oxygen loss. The occurrence of a sharp peak, instead of a broad one, may be due to the small, loose-packed sample that would promote oxygen diffusion. The three smaller peaks are probably associated with latticeordering in the lower temperature range. These peaks were found to be characteristic for $\mathrm{U}_{3} \mathrm{O}_{8}$ from three different sources and also for $\mathrm{U}_{3} \mathrm{O}_{8}$ prepared by calcining $\mathrm{UO}_{2}$ in air. 


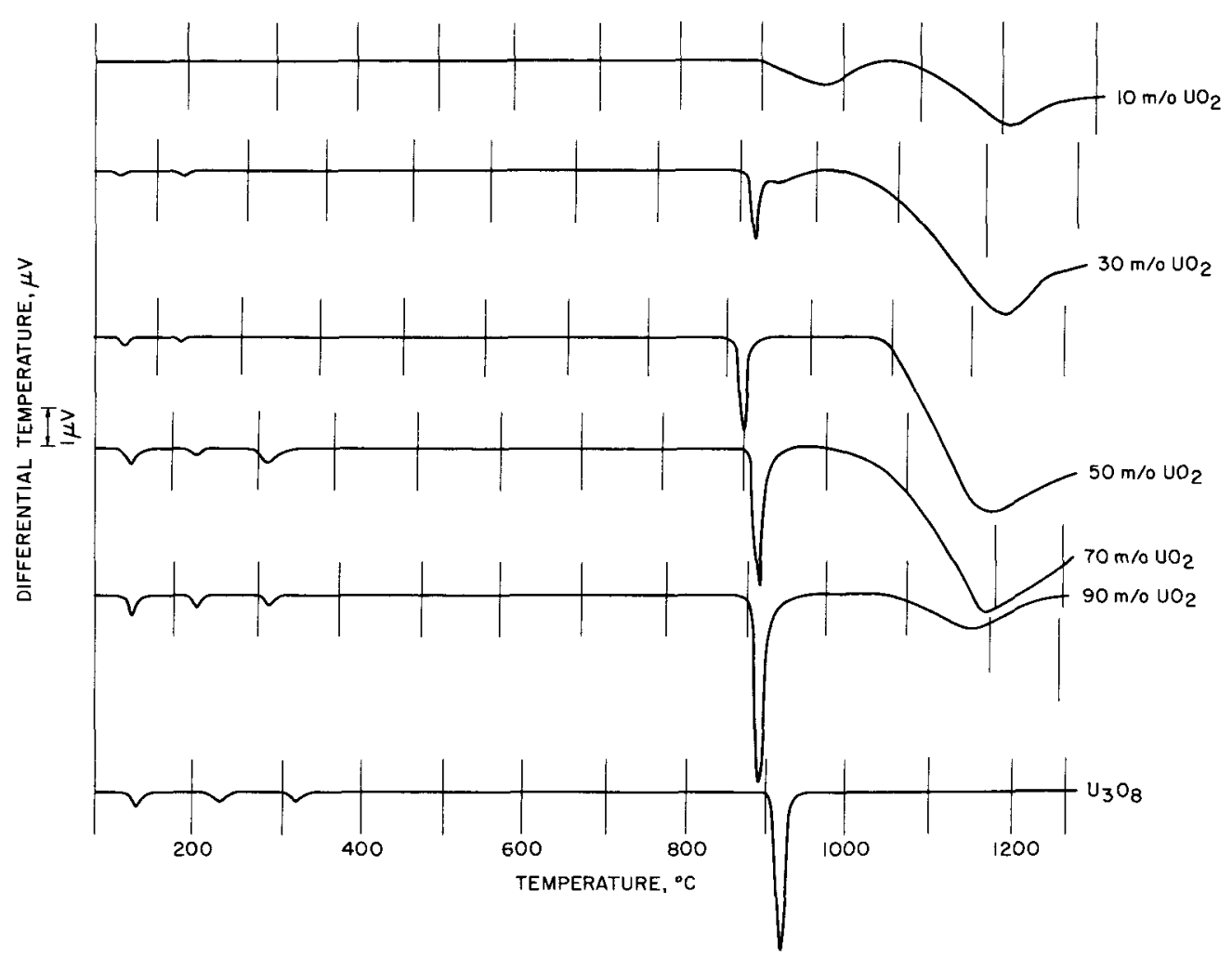

Fig. 6. Thermal Effects Occurring during the Formation of Solid Solutions from $\mathrm{ThO}_{2}-\mathrm{U}_{3} \mathrm{O}_{8}$ Mixtures

Samples containing 5 and $2.5 \mathrm{~m} / \mathrm{O} \mathrm{UO}_{2}$ showed no sharp thermal peaks and only a general trend toward an endothermic reaction above $1000^{\circ} \mathrm{C}$.

The $\mathrm{ThO}_{2}-10 \mathrm{~m} / \mathrm{OUO}_{2}$ composition had two broad endothermic peaks between 900 and $1300^{\circ} \mathrm{C}$. The first corresponded to the major peak of $\mathrm{U}_{3} \mathrm{O}_{8}$, and the second was the reaction to form solid solution. As the concentration of $\mathrm{UO}_{2}$ in the compositions was increased, the magnitude and sharpness of the endothermic peaks increased.

The solid-solution process is endothermic in the $\mathrm{ThO}_{2}-\mathrm{UO}_{2}\left(\mathrm{U}_{3} \mathrm{O}_{8}\right)$ system. Solid solutions begin to form at approximately $1050^{\circ} \mathrm{C}$, just after the sharp endothermic peak associated with $\mathrm{U}_{3} \mathrm{O}_{8}$. Evidently the loss of oxygen from the $\mathrm{U}_{3} \mathrm{O}_{8}$ produces a reactive powder and promotes the solidsolution reaction.

The extent of the endothermic reaction during solid-solution formation was much less for $\mathrm{ThO}_{2}-90 \mathrm{~m} / \mathrm{oUO}_{2}$ than for other compositions. This composition does not form a stable, single-phase solid solution on heating in air. 


\section{DENSIFICATION BEHAVIOR}

Solid solutions of thoria-urania are readily fabricated and sintered to densities greater than $90 \%$ of theoretical. Sintering of compositions to equivalent densities, however, requires considerable manipulation of the forming processes as the concentration of urania in the composition is increased.

The purpose of this study was to determine and compare the densification behavior of both stoichiometric and hyperstoichiometric thoriaurania solid solutions of a wide compositional range. The variation of stoichiometry was also determined and is discussed in the following section of this report.

Solid-solution compositions were prepared from Mallinckrodt $\mathrm{U}_{3} \mathrm{O}_{8}$, $\mathrm{UO}_{2}$, and Lindsay Code $112 \mathrm{ThO}_{2}$. Before usage, the $\mathrm{U}_{3} \mathrm{O}_{8}$ and $\mathrm{ThO}_{2}$ were calcined in air at $1000^{\circ} \mathrm{C}$ and cooled slowly. Calcination was carried out to insure complete oxidation of the $\mathrm{U}_{3} \mathrm{O}_{8}$ and decomposition of any residual material in the $\mathrm{ThO}_{2}$.

Compositions in the range of 2.5 to $90 \mathrm{~m} / \mathrm{o} \mathrm{UO}_{2}$ were prepared by dry ball-milling and cold-pressing to form cylindrical samples. To have a basis for comparing densification characteristics, all samples were pressed to bulk densities in the range of $6.0 \pm 0.2 \mathrm{~g} / \mathrm{cc}$. All samples were pressed without the use of moisture or binders since weight-loss measurements were to be made.

Sintering was carried out both in hydrogen and in air over a $24 \mathrm{mr}$ period of heating to maximum temperature, followed by an 18-hr soaking period at temperature. The extended soaking period was used to insure equilibrium conditions. In the case of hydrogen sintering, all samples were cooled to room temperature in hydrogen to minimize oxidation.

The progress of densification was determined by measuring shrinkage and bulk density. Shrinkage measurements were made for $\mathrm{ThO}_{2}-\mathrm{U}_{3} \mathrm{O}_{8}$ samples sintered both in air and hydrogen, and for $\mathrm{ThO}_{2}-\mathrm{UO}_{2}$ samples sintered in hydrogen at temperatures from 1200 to $1650^{\circ} \mathrm{C}$.

Shrinkage results for air-sintered $\mathrm{ThO}_{2}-\mathrm{U}_{3} \mathrm{O}_{8}$ compositions are shown in Fig. 7. The addition of $\mathrm{U}_{3} \mathrm{O}_{8}$ in amounts up to $10 \mathrm{~m} / \mathrm{o} \mathrm{UO}_{2}$ (equivalent) results in a greater shrinkage than that found for pure $\mathrm{ThO}_{2}$ at all temperatures. At the higher temperatures, $5 \mathrm{~m} / \mathrm{O} \mathrm{UO}_{2}$ yielded a maximum shrinkage. The addition of $\mathrm{U}_{3} \mathrm{O}_{8}$ above this concentration resulted in a decreased shrinkage, with a minimum occurring at $50 \mathrm{~m} / \mathrm{O} \mathrm{UO}_{2}$. At the lower sintering temperatures, an expansion over original dimensions occurred. The expansion noted for $90 \mathrm{~m} / \mathrm{o} \mathrm{UO}_{2}$ at $1500^{\circ} \mathrm{C}$ and above was a result of oxidation of the unstable solid solution during the cooling cycle. 


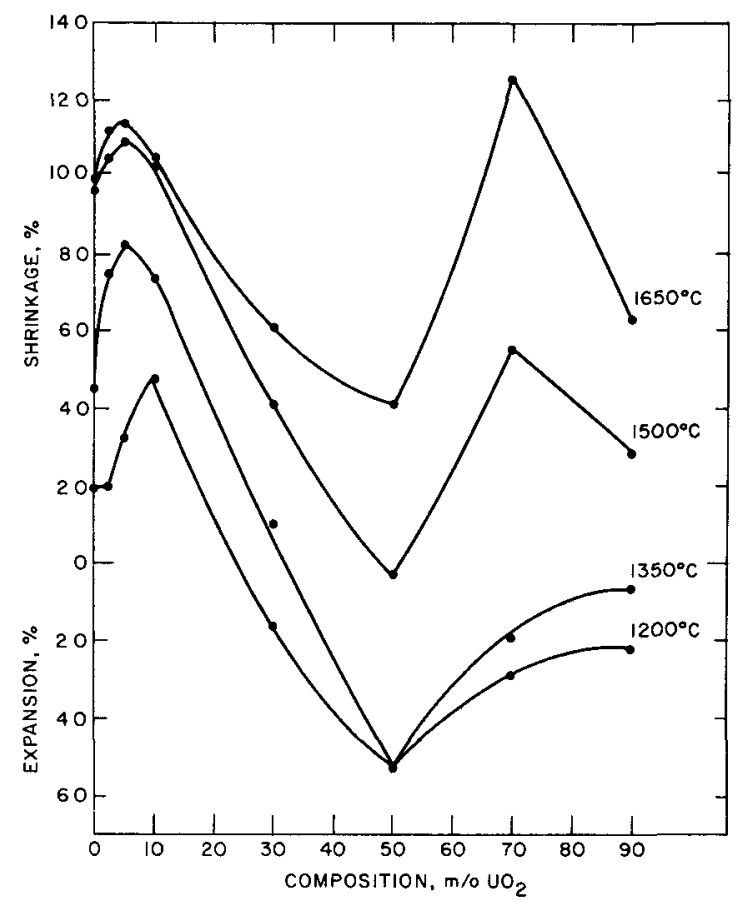

106-5276 Rev. 1

Fig. 7. Shrinkage Characteristics of Air-sintered $\mathrm{ThO}_{2}-\mathrm{U}_{3} \mathrm{O}_{8}$ Compositions Parallel to Pressing Direction
The procedure of forming all samples to the same green density required considerably greater pressing pressures for some compositions. To minimize the pressure effects, shrinkage was also measured perpendicular to the pressing direction.

Shrinkage perpendicular to the pressing direction was approximately the same as that parallel to the pressing direction. At the higher sintering temperatures, the shrinkage was approximately the same for 2.5 to $10 \mathrm{~m} / \mathrm{o}$ $\mathrm{UO}_{2}$ variation in composition. The differences noted between the two directions were attributed to lamination weakness. However, there were no visible laminations in any samples before sintering.

The shrinkage characteristics parallel to the pressing direction are shown in Fig. 8 for 10 to $90 \mathrm{~m} / \mathrm{OUO}_{2}$

compositions prepared from $\mathrm{ThO}_{2}-\mathrm{U}_{3} \mathrm{O}_{8}$ and sintered in hydrogen. At the lower temperatures, the shrinkage behavior of the hydrogen-sintered $\mathrm{U}_{3} \mathrm{O}_{8}$ compositions was similar to those air-sintered. Although to a lesserdegree, there was a minimum shrinkage for $50 \mathrm{~m} / \mathrm{o} \mathrm{UO}_{2}$ at $1350^{\circ} \mathrm{C}$ and a longitudinal expansion for the same composition at $1200^{\circ} \mathrm{C}$. A temperature of $1500^{\circ} \mathrm{C}$ in hydrogen was required to yield appreciable shrinkages. In the direction perpendicular to pressing, there was no actual increase over pressed dimensions for the $50 \mathrm{~m} / \mathrm{o}$ $\mathrm{UO}_{2}$ composition although a minimum shrinkage was shown for that composition at lower temperatures. There was no indication of instability of the $90 \mathrm{~m} / \mathrm{O} \mathrm{UO}_{2}$ composition when sintered in hydrogen.

Compositions in the range of 10 to $90 \mathrm{~m} / \mathrm{o} \mathrm{UO}_{2}$ prepared from $\mathrm{ThO}_{2}$ $\mathrm{UO}_{2}$ were sintered in hydrogen. These compositionswere expected to behave similarly to the hydrogen-sintered $\mathrm{ThO}_{2}-\mathrm{U}_{3} \mathrm{O}_{8}$ compositions since there

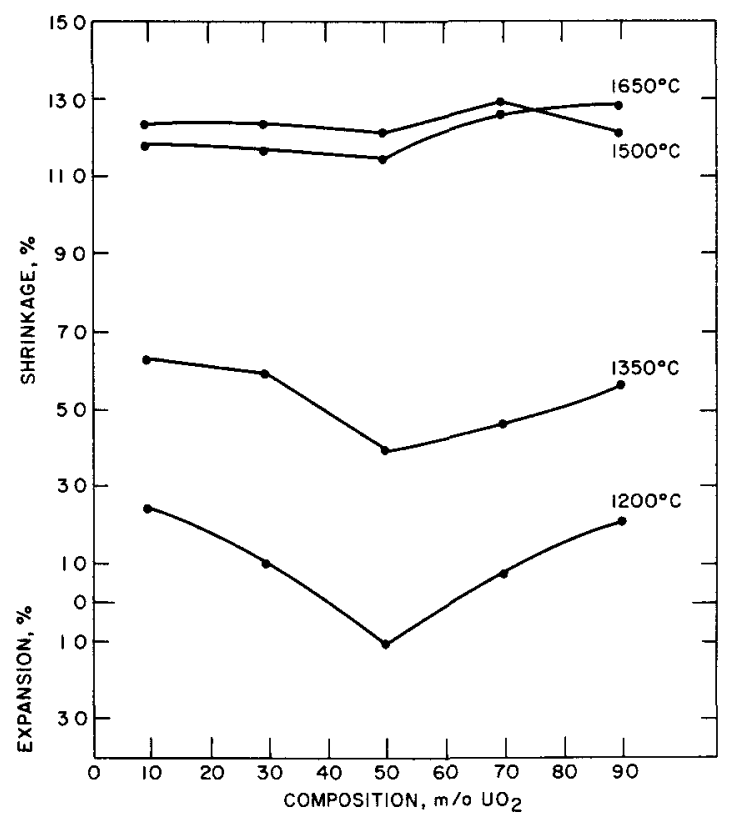

106-5272 Rev. 1

Fig. 8. Shrinkage Characteristics of Hydrogensintered $\mathrm{ThO}_{2}-\mathrm{U}_{3} \mathrm{O}_{8}$ Compositions Parallel to Pressing Direction 


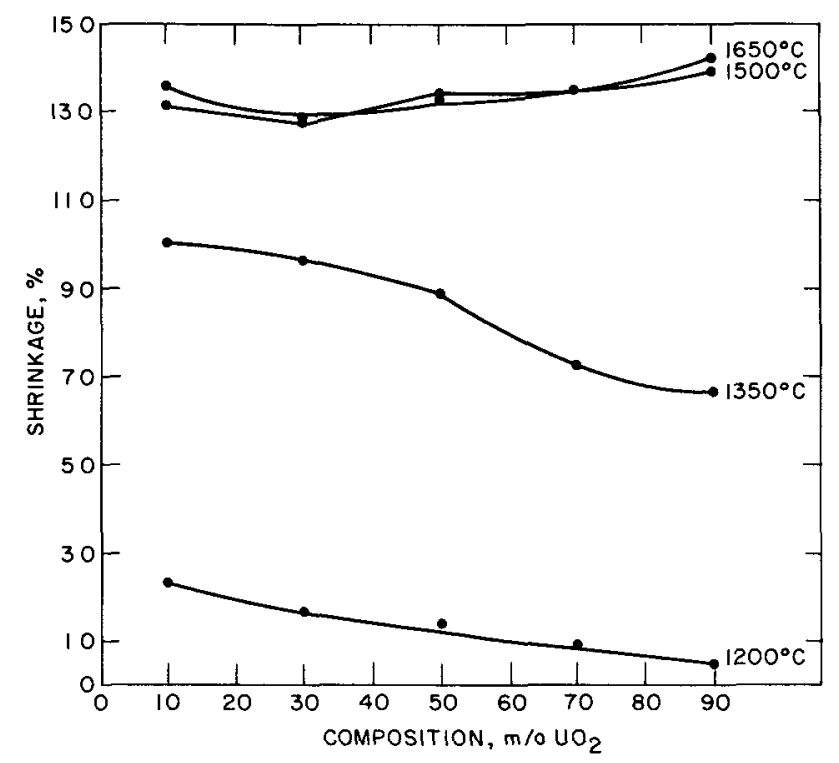

106-5275 Rev. 1

Fig. 9. Shrınkage Characterıstıcs of Hydrogen-sintered $\mathrm{ThO}_{2}-\mathrm{UO}_{2}$ Compositions Perpendicular to Pressing Direction should be only differences in grain size and perhaps surface activity due to the early reduction of $\mathrm{U}_{3} \mathrm{O}_{8} \rightarrow$ $\mathrm{UO}_{2}$. Shrinkage measurements perpendicular to the pressing direction (Fig. 9) showed no tendency for the minimum shrinkage found in other samples at $50 \mathrm{~m} / \mathrm{o} \mathrm{UO}_{2}$. A temperature of $1350^{\circ} \mathrm{C}$ was required to yield any appreciable shrinkage, and there was no significant difference in shrinkages at 1500 and $1600^{\circ} \mathrm{C}$. The trends observed in shrinkage behavior resulting from experimental variables are summarized in Fig. 10.

The densification behavior of $\mathrm{ThO}_{2}-\mathrm{U}_{3} \mathrm{O}_{8}$ and $\mathrm{ThO}_{2}-\mathrm{UO}_{2}$ compositions was determined by measuring the percentage change in

bulk density for samples formed with a uniform pressed density. The results for 0 to $90 \mathrm{~m} / \mathrm{o} \mathrm{UO}_{2}$ compositions prepared from $\mathrm{ThO}_{2}-\mathrm{U}_{3} \mathrm{O}_{8}$ and sintered in air are shown in Fig. 11 .

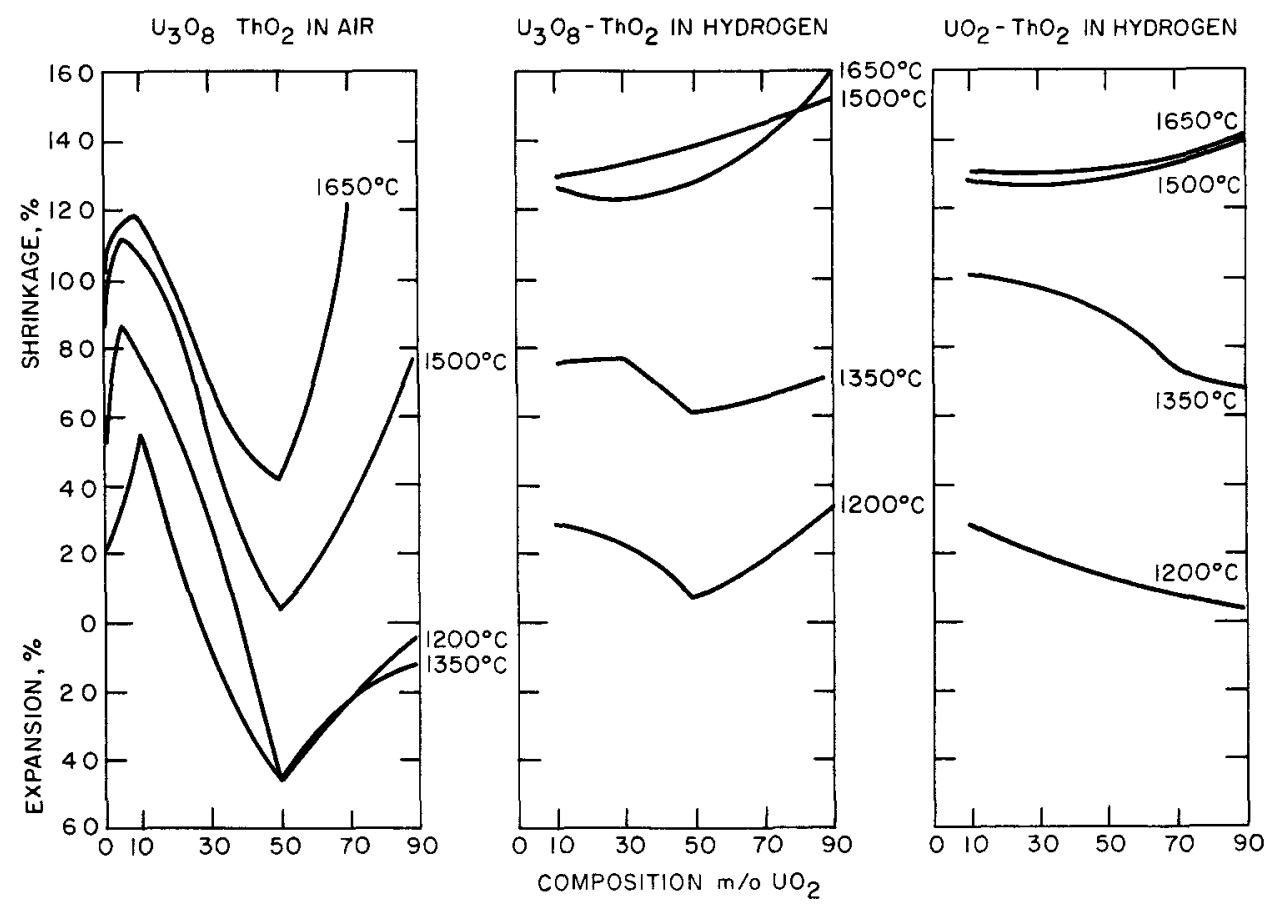

106-6302 Rev. 1

Fig. 10. Effects of Composition and Heat Treatment on Shrmkage Behavior 


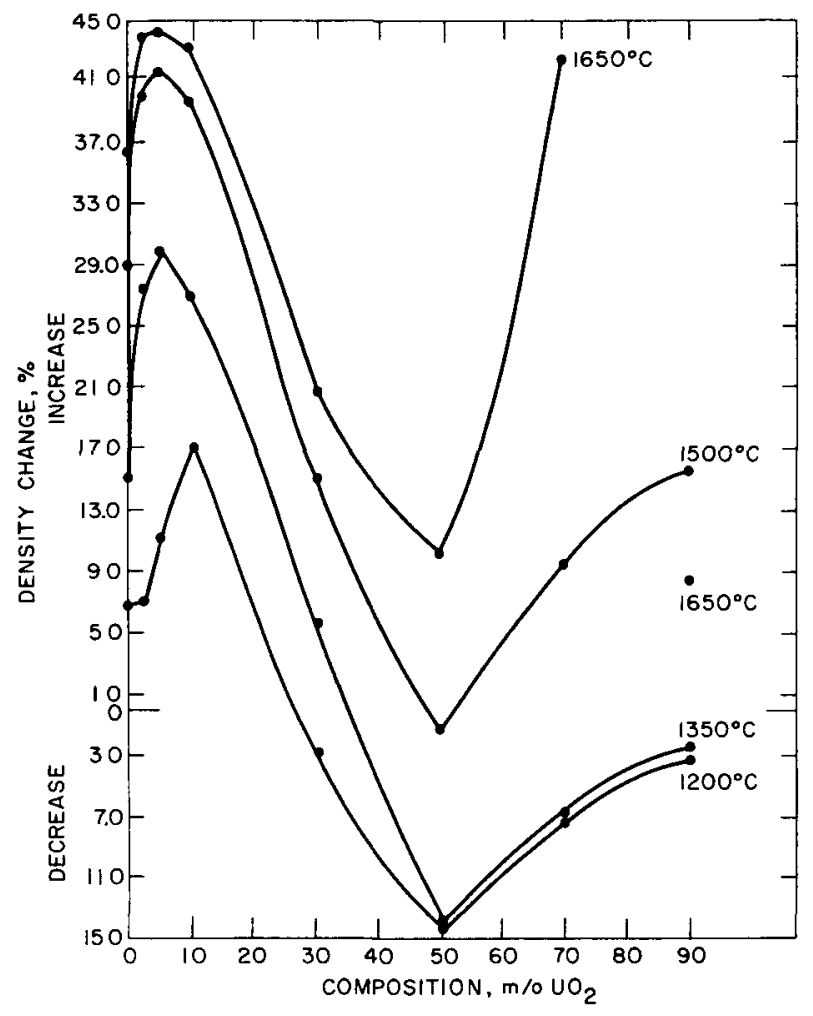

106-5270 Rev. 1

Fig. 11. Effects of Composition and Sintering Temperature on Densification of $\mathrm{ThO}_{2}-\mathrm{U}_{3} \mathrm{O}_{8}$ Compositions Sintered in Air
The addition to $\mathrm{ThO}_{2}$ of 2.5 to $10 \mathrm{~m} / \mathrm{O} \mathrm{UO}_{2}$ resulted in rapid densification of the samples. At the higher temperatures, where solid solution would be complete, the maximum density change occurred at $5 \mathrm{~m} / \mathrm{o} \mathrm{UO}_{2}$. The addition of 30 to $50 \mathrm{~m} / \mathrm{o} \mathrm{UO}_{2}$ resulted in densities less than that for pure $\mathrm{ThO}_{2}$. At the lower temperature, samples with 30 to $90 \mathrm{~m} / \mathrm{O} \mathrm{UO}_{2}$ had a lower sintered density than the original pressed density. At all temperatures, the $50 \mathrm{~m} / \mathrm{O} \mathrm{UO}_{2} \mathrm{com}$ position resulted in a minimum density. The maximum bulk density obtained was $8.8 \mathrm{~g} / \mathrm{cc}$, and the minimum was $5.1 \mathrm{~g} / \mathrm{cc}$.

\section{The density change for} hydrogen-sintered $\mathrm{ThO}_{2}-\mathrm{U}_{3} \mathrm{O}_{8}$ compositions in the range of 10 to $90 \mathrm{~m} / \mathrm{O} \mathrm{UO}_{2}$ is shown in Fig. 12 . The $50 \mathrm{~m} / \mathrm{O} \mathrm{UO}_{2}$ composition again shows a minimum density change at the lower temperatures, with a decrease from pressed density

when sintered at $1200^{\circ} \mathrm{C}$. The greatest change in densification behavior was brought about by temperature increase. The maximum density achieved in this series was $9.5 \mathrm{~g} / \mathrm{cc}$, and the minimum was $5.9 \mathrm{~g} / \mathrm{cc}$.

Hydrogen sintering of $\mathrm{ThO}_{2}-\mathrm{UO}_{2}$ samples containing from 10 to $90 \mathrm{~m} / \mathrm{O} \mathrm{UO}_{2}$ resulted in density changes as shown in Fig. 13. There was no appreciable densification below the sintering temperature of $1350^{\circ} \mathrm{C}$. The reversal of the densification curves for 1350 and $1500^{\circ} \mathrm{C}$ sintering temperatures indicates that the high- $\mathrm{UO}_{2}$ compositions required increased temperature to promote solid solution.

The densification of air-sintered $\mathrm{ThO}_{2}-\mathrm{U}_{3} \mathrm{O}_{8}$ compositions was very sensitive to compositional change. Compositions containing $10 \mathrm{~m} / \mathrm{O} \mathrm{UO}_{2}$ equivalent and less were the most readily densified, and the change due to composition was not large within this compositional range, at the higher temperatures. The effect was similar to that noted for $\mathrm{UO}_{2}$, where some departure from stoichiometry increases the sinterability of the material. In the range of 30 to $90 \mathrm{~m} / 0 \mathrm{UO}_{2}$, bulk-density increases were considerably less than the lower urania compositions, and, in some cases, the sintered density was less than the pressed density. These density measurements 
are not true grain or particle densities, and the effects noted are due primarily to the change of porosity and are the combined result of shrinkage and all reactions that may affect pore structure. If there were no interfering reactions, some sort of progressive change in shrinkage and bulk density would be expected from increasing the concentration of one component. The changes noted here were probably due to a combined effect of solidsolution-reaction rate, oxygen loss through pores during the reactionsintering, and reoxidation during cooling. Further tests have shown that the $50 \mathrm{~m} / \mathrm{O} \mathrm{UO}_{2}$ equivalent composition may be densified at $1500^{\circ} \mathrm{C}$ by increasing the bulk density of the pressed sample.

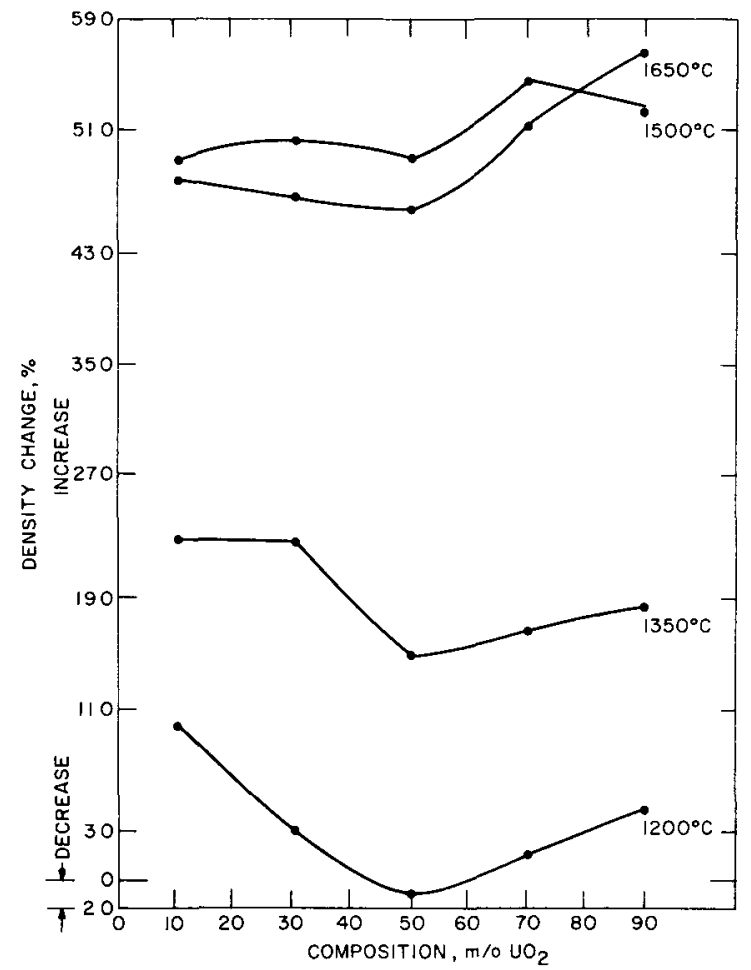

$106-6030$ Rev. 1

Fig. 12. Effects of Composition and Sintering Temperature on Densification of $\mathrm{ThO}_{2}-\mathrm{U}_{3} \mathrm{O}_{8}$ Compositions Sintered in Hydrogen

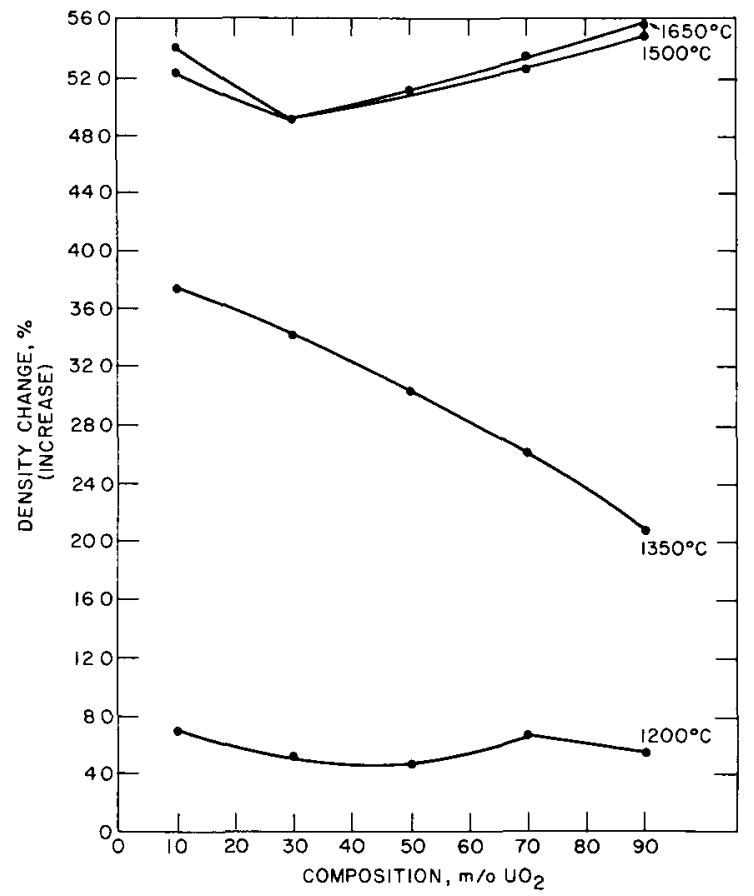

106-5278 Rev. 1

Fig. 13. Effects of Composition and Sintering Temperature on Densification of $\mathrm{ThO}_{2}-\mathrm{UO}_{2}$ Compositions Sintered in Hydrogen

Bulk-density changes of hydrogen-sintered $\mathrm{ThO}_{2}-\mathrm{U}_{3} \mathrm{O}_{8}$ and $\mathrm{ThO}_{2}-\mathrm{UO}_{2}$ were not as sensitive to compositional changes as were the air-sintered materials. Hydrogen-sintered $\mathrm{ThO}_{2}-\mathrm{UO}_{2}$ compositions showed no appreciable densification or variation in density when sintered at $1200^{\circ} \mathrm{C}$. This result indicates that sintering of the solid solution, or the solid-solution reaction, has not progressed to a great degree. Further increase in temperature to $1500^{\circ} \mathrm{C}$ rapidly promoted sintering, but increasing the temperature to $1650^{\circ} \mathrm{C}$ produced no significant effect. The results for hydrogensintered $\mathrm{ThO}_{2}-\mathrm{U}_{3} \mathrm{O}_{8}$ compositions are similar to those for $\mathrm{ThO}_{2}-\mathrm{UO}_{2}$, and 
the differences noted may well be due to changes in the character of the pressed samples resulting from oxygen release through the pore structure before the solid-solution reaction and densification.

In general, the densification of the air-sintered materials was influenced more by compositional change than by temperature, the opposite effect being noted for the hydrogen-sintered materials. Hydrogen sintering resulted in the highest sintered densities. The, results of densification studies are summarized in Fig. 14.
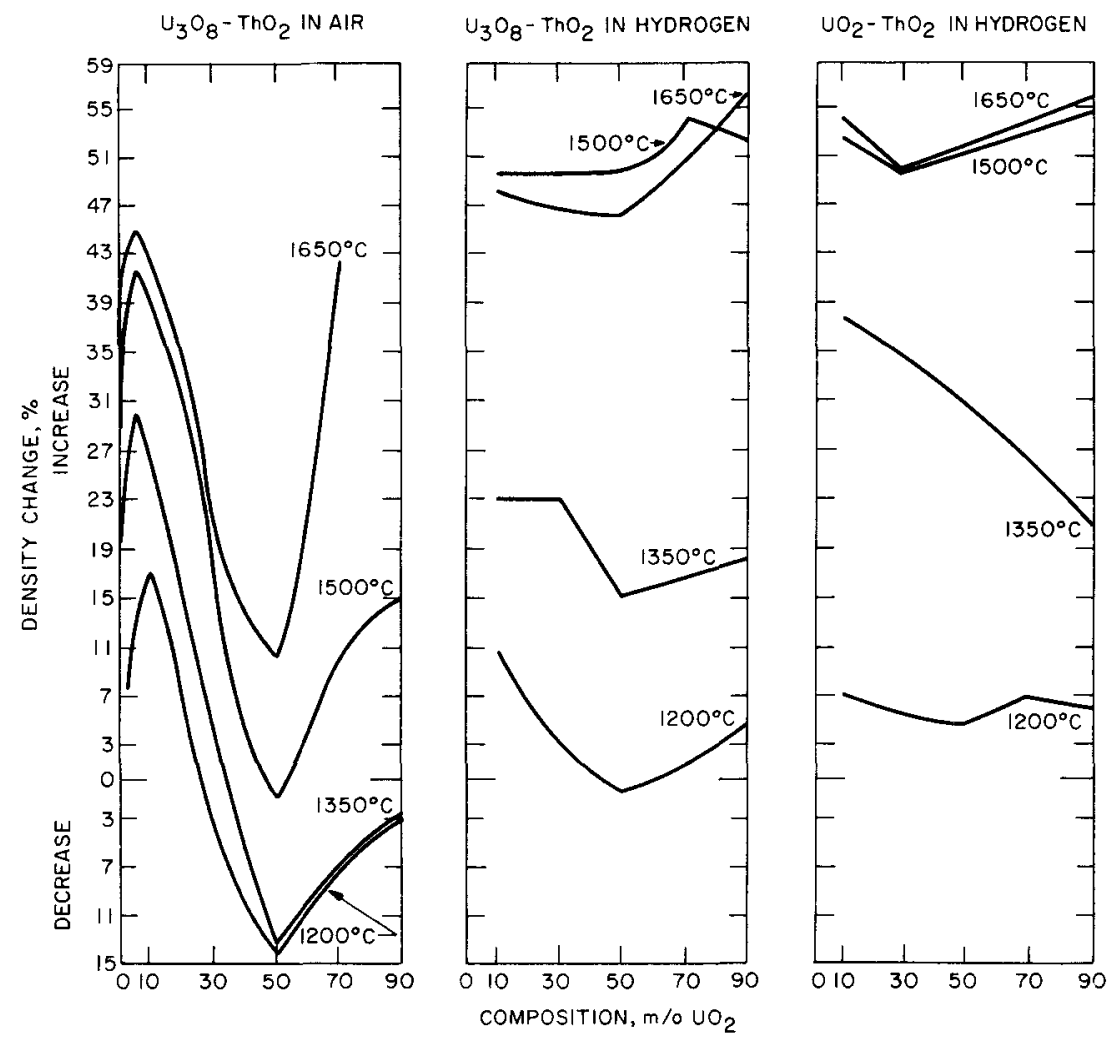

Fig. 14

Effects of Composition and Heat Treatment on Densification

106-6293 Rev. 1

\section{STOICHIOMETRY OF AIR-SINTERED MATERIALS}

The air-sintered $\mathrm{ThO}_{2}-\mathrm{U}_{3} \mathrm{O}_{8}$ and hydrogen-sintered $\mathrm{ThO}_{2}-\mathrm{UO}_{2}$ or $\mathrm{ThO}_{2}-\mathrm{U}_{3} \mathrm{O}_{8}$ systems differ in that a continuous, stoichiometric, solidsolution series is formed for the hydrogen-sintered materials, while a stability-limited, hyperstoichiometric, solid-solution series is formed for the air-sintered materials.

Samples prepared as described in the previous section were used to determine the effects of composition and sintering temperature on the degree of hyperstoichiometry of the air-sintered solid solution. Special care was used to prevent the inclusion of any volatile materials in the sample batches before sintering. All samples were weighed to $0.1 \mathrm{mg}$ before and after sintering, for weight-loss determination. Stoichiometry of the solid solutions was determined by calculation from these measurements and from the weight losses encountered during subsequent reduction 
of the samples in hydrogen at $1000^{\circ} \mathrm{C}$. The content of uranium in the solid solutions was calculated by using reduction to $\mathrm{UO}_{2.00}$ as the basis.

The weight changes resulting from the reaction-sintering process are shown in Table IV. For ease of interpretation, the weight losses have been expressed in terms of loss in grams per gram of $\mathrm{U}_{3} \mathrm{O}_{8}$ in the original composition. Thorium oxide was run as a standard with all determinations, and no detectable weight change was noted in the temperature range used. The weight losses are considered as being related entirely to the $\mathrm{U}_{3} \mathrm{O}_{8}$. On this basis, a ratio of 0.038 would indicate complete conversion of $\mathrm{U}_{3} \mathrm{O}_{8} \rightarrow \mathrm{UO}_{2}$ during the solid-solution reaction, and higher values of this ratio would indicate volatilization of urania during sintering. The values for the $\mathrm{ThO}_{2}-$ $2.5 \mathrm{~m} / \mathrm{OUO}_{2}$ and $\mathrm{ThO}_{2}-5 \mathrm{~m} / \mathrm{oUO}_{2}$ compositions indicate urania loss at all temperatures used. The volatility from these compositions at low temperatures may be a result of inhomogeneity due to mixing and the subsequent concentration of $\mathrm{U}_{3} \mathrm{O}_{8}$. All compositions showed evidence of urania loss at the $1650^{\circ} \mathrm{C}$ sintering temperature. The very low ratios found at the lower temperatures for the $\mathrm{ThO}_{2}-70 \mathrm{~m} / \mathrm{oUO}_{2}$ and $\mathrm{ThO}_{2}-90 \mathrm{~m} / \mathrm{oUO}_{2}$ compositions indicate either a slow reaction rate or instability of the solid solution during cooling. In the case of the $\mathrm{ThO}_{2}-90 \mathrm{~m} / \mathrm{OUO}_{2}$ composition, instability has been shown, and the solid solution oxidizes to form a two-phase system on cooling in air.

TABLE IV. Weight Loss for Air-sintered $\mathrm{ThO}_{2}-\mathrm{U}_{3} \mathrm{O}_{8}$ Compositions

\begin{tabular}{|c|c|c|c|c|}
\hline \multirow{2}{*}{$\begin{array}{c}\mathrm{UO}_{2} \\
\text { Content, } \\
\mathrm{m} / \mathrm{o}\end{array}$} & \multicolumn{3}{|c|}{$\begin{array}{c}\text { Weight Loss in grams per gram of } \\
\mathrm{U}_{3} \mathrm{O}_{8} \text { in Composition* }\end{array}$} \\
\cline { 2 - 5 } & $1200^{\circ} \mathrm{C}$ & $1350^{\circ} \mathrm{C}$ & $1500^{\circ} \mathrm{C}$ & $1650^{\circ} \mathrm{C}$ \\
\hline 2.5 & 0.080 & 0.100 & 0.138 & 0.191 \\
5.0 & 0.040 & 0.050 & 0.047 & 0.061 \\
10.0 & 0.022 & 0.023 & 0.021 & 0.048 \\
30.0 & 0.012 & 0.010 & 0.011 & 0.056 \\
50.0 & 0.013 & 0.012 & 0.013 & 0.054 \\
70.0 & 0.008 & 0.011 & 0.027 & 0.057 \\
90.0 & 0.003 & 0.006 & 0.034 & - \\
\hline
\end{tabular}

*Values greater than 0.038 indicate volatilization of urania.

The results of the determination of the degree of hyperstoichiometry of these solid solutions are shown in Table V. Solid solutions containing less than $30 \mathrm{~m} / \mathrm{o} \mathrm{UO}_{2}$ were very nearly stoichiometric at all sintering temperatures. There was a general tendency for a greater departure from stoichiometry as the concentration of $\mathrm{UO}_{2}$ in the solid solution was increased. The extremely high values for the $\mathrm{ThO}_{2}-90 \mathrm{~m} / \mathrm{OUO}_{2}$ composition show the instability of the solid solution during cooling and possibly incomplete reaction during heating. When the temperature was sufficient for 
complete reaction, the $\mathrm{ThO}_{2}-50 \mathrm{~m} / \mathrm{oUO}_{2}$ composition exhibited an oxygenmetal ratio of 2.25 , corresponding to the $\mathrm{U}_{4} \mathrm{O}_{9}$ ratio, and this ratio was stable for all sintering temperatures used. A neutron-diffraction study of this particular composition is included in a later section of this report (p. 37).

TABLE V. Ratios of Oxygen to Total Metal for Air-sintered $\mathrm{ThO}_{2}-\mathrm{U}_{3} \mathrm{O}_{8}$ Compositions

\begin{tabular}{|c|c|c|c|c|}
\hline \multirow{2}{*}{$\begin{array}{c}\mathrm{UO}_{2} \\
\text { Content, } \\
\mathrm{m} / \mathrm{o}\end{array}$} & $1200^{\circ} \mathrm{C}$ & $1350^{\circ} \mathrm{C}$ & $1500^{\circ} \mathrm{C}$ & $1650^{\circ} \mathrm{C}$ \\
\cline { 2 - 5 } & 2.05 & 2.06 & 2.06 & 2.02 \\
2.5 & 2.02 & 2.03 & 2.03 & 2.03 \\
5.0 & 2.06 & 2.06 & 2.06 & 2.05 \\
10.0 & 2.17 & 2.18 & $\mathrm{n} . \mathrm{d}$ & 2.17 \\
30.0 & 2.30 & 2.25 & 2.25 & 2.25 \\
50.0 & 2.40 & 2.38 & 2.32 & 2.32 \\
70.0 & 2.60 & 2.58 & 2.52 & - \\
90.0 & & & & \\
\hline
\end{tabular}

As a check of the reproducibility of the stoichiometry data, four separate preparations of materials were given individual sintering treat-

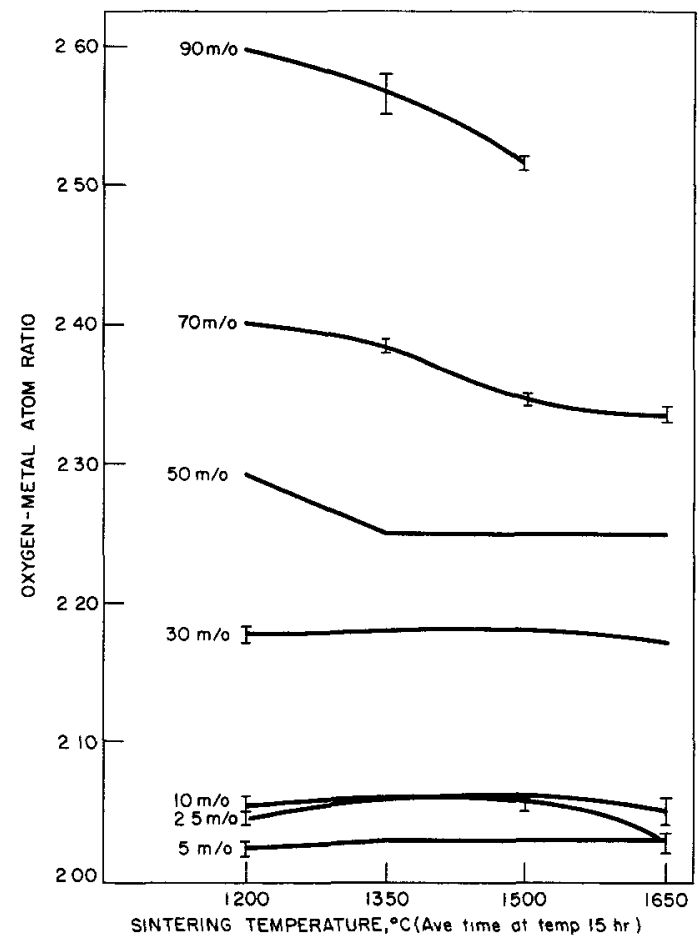

$106-6299$

Fig. 15. Extent of Hypers toichiometry of Airsintered $\mathrm{ThO}_{2}-\mathrm{U}_{3} \mathrm{O}_{8}$ Compositions ments. Materials were sintered in the range of 1200 to $1650^{\circ} \mathrm{C}$ and held at temperature for $15 \mathrm{hr}$ for equilibration. The results of these tests are shown in Fig. 15. The values were very reproducible as shown by the spread of the data. Each solid-solution composition tends to approach a constant oxygenmetal atom ratio with increasing temperature. The exception is the $\mathrm{ThO}_{2}-$ $90 \mathrm{~m} / \mathrm{OUO}_{2}$ composition, which is a two-phase system.

The extent of hyperstoichiometry resulting from long-time reactionsintering in air appears to be a nearequilibrium value dependent upon composition. Solid solutions formed by sintering $\mathrm{ThO}_{2}-\mathrm{U}_{3} \mathrm{O}_{8}$ mixtures in air for $15 \mathrm{hr}$ at $1500^{\circ} \mathrm{C}$ were reduced to stoichiometry by heating in hydrogen for $15 \mathrm{hr}$ at $1000^{\circ} \mathrm{C}$ and then reheated in flowing oxygen for $100 \mathrm{hr}$ at $1000^{\circ} \mathrm{C}$. The results of this treatment are shown in Fig. 16. 


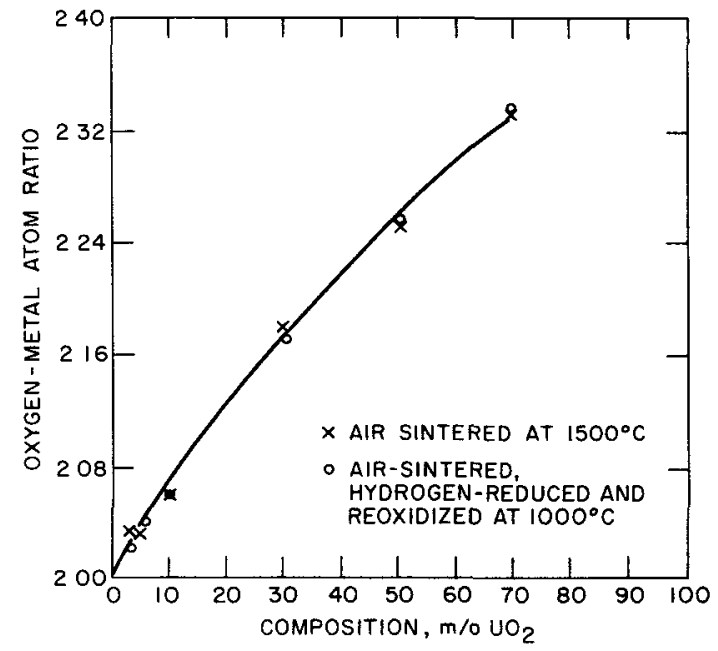

106-6253 Rev. 1

Fig. 16. Reproducibility of Hyperstolchiometry by Reduction-Oxidation of Solid Solutions Formed from $\mathrm{ThO}_{2}-\mathrm{U}_{3} \mathrm{O}_{8}$
The oxygen-metal atom ratios resulting from air-sintering were nearly the same as those obtained by reduction and subsequent oxidation. In the range of compositions up to $\mathrm{ThO}_{2}-5 \mathrm{~m} / \mathrm{OUO}_{2}$, the solid solutions are nearly stoichiometric $\left(\mathrm{U}_{0.05} \mathrm{Th}_{0.95} \mathrm{O}_{2.03}\right)$. Weight-los s determinations indicate that these compositions are susceptible to urania loss by volatilization during sintering.

\section{STRUCTURAL EFFECTS OF STOICHIOMETRY}

Lattice-parameter measurements were made for solid solutions resulting from the following treatments: (1) $\mathrm{ThO}_{2}-$ $\mathrm{U}_{3} \mathrm{O}_{8}$ air-sintered at $1500^{\circ} \mathrm{C}$ for $18 \mathrm{hr}$, (2) air-sintered samples reduced in hydrogen at $1000^{\circ} \mathrm{C}$ for $15 \mathrm{hr}$, and (3) reduced samples reoxidized in flowing oxygen at $1000^{\circ} \mathrm{C}$ for $100 \mathrm{hr}$. Computer calculation of cell size was made from X-ray diffraction data for each of these materials; the results are shown in Table VI.

TABLE VI. Lattice-parameter Determinations for Solid Solutions Formed from $\mathrm{ThO}_{2}-\mathrm{U}_{3} \mathrm{O}_{8}$ and Treated as Shown

\begin{tabular}{|c|c|c|c|c|c|c|c|}
\hline \multirow{3}{*}{\multicolumn{2}{|c|}{$\begin{array}{c}\text { Composition, } \\
\mathrm{m} / \mathrm{o}\end{array}$}} & \multicolumn{6}{|c|}{ X-ray Lattice Parameter, $\AA$} \\
\hline & & \multicolumn{3}{|c|}{ Alr-sintered at $1500^{\circ} \mathrm{C}$} & \multicolumn{3}{|c|}{ Alr-sintered at $1650^{\circ} \mathrm{C}$} \\
\hline & & \multirow{2}{*}{$\begin{array}{c}\text { As } \\
\text { Sintered }\end{array}$} & \multirow{2}{*}{$\begin{array}{c}\mathrm{H}_{2} \text { Reduced } \\
\text { at } 1000^{\circ} \mathrm{C}\end{array}$} & \multirow{2}{*}{$\begin{array}{c}\text { Reoxidized } \\
\text { in } \mathrm{O}_{2} \text { at } \\
1000^{\circ} \mathrm{C}\end{array}$} & \multirow{2}{*}{$\begin{array}{c}\text { As } \\
\text { Sintered }\end{array}$} & \multirow{2}{*}{$\begin{array}{c}\mathrm{H}_{2} \text { Reduced } \\
\text { at } 1000^{\circ} \mathrm{C}\end{array}$} & \multirow{2}{*}{$\begin{array}{c}\text { Reoxidized } \\
\text { in } \mathrm{O}_{2} \text { at } \\
1000^{\circ} \mathrm{C}\end{array}$} \\
\hline $\mathrm{UO}_{2}$ & $\mathrm{ThO}_{2}$ & & & & & & \\
\hline 2.5 & 97.5 & 5.5940 & 5.5942 & 5.5943 & 5.5949 & 5.5951 & 5.5954 \\
\hline 5.0 & 95.0 & 5.5914 & 5.5906 & 5.5900 & 5.5938 & 5.5940 & 5.5946 \\
\hline 10.0 & 90.0 & 5.5827 & 5.5865 & 5.5839 & - & - & - \\
\hline 30.0 & 70.0 & 5.5432 & 5.5589 & 5.5427 & 5.5435 & 5.5583 & 5.5428 \\
\hline 50.0 & 50.0 & 5.4951 & 5.5326 & 5.4981 & 5.4982 & 5.5334 & 5.4987 \\
\hline 70.0 & 30.0 & 5.4745 & 5.5062 & 5.4628 & 5.4706 & 5.5070 & 5.4609 \\
\hline
\end{tabular}

Solid solutions formed in the thoria-urania system exhibit a cubic structure of the fluorite type. Air-sintered solid solutions formed from $\mathrm{ThO}_{2}-\mathrm{U}_{3} \mathrm{O}_{8}$ have unit-cell sizes smaller than those of the stoichiometric solid solutions formed from $\mathrm{ThO}_{2}-\mathrm{UO}_{2}$.

In the compositional range studied, the change in cell size with composition was linear, as shown in Fig. 17. The lattice parameters of the solid solutions formed by air-sintering and by subsequent reductionreoxidation treatment are in close agreement. The reoxidized materials 
tended to have a slightly smaller cell size indicative of a greater degree of oxidation than the air-sintered materials.

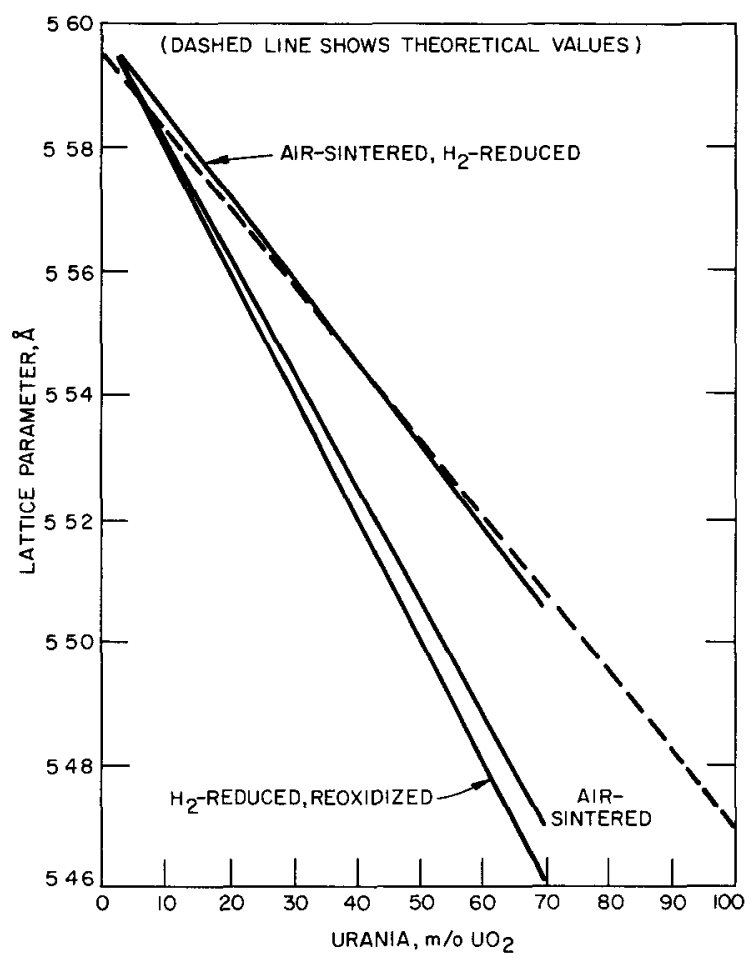

$106-6252$

Fig. 17. Lattice Parameters for Stoichiometric and Hyperstoichiometric $\mathrm{ThO}_{2}-\mathrm{UO}_{2}$ Solid Solutions
The reduction of air-sintered solid solutions by hydrogen treatment, at a temperature where no further reaction could occur, resulted in an increase in cell sizes to values in close agreement with theoretical values for the system. The disagreement of the hydrogen-reduced values with the theoretical curve may be due to volatilization of urania in the low $-\mathrm{UO}_{2}$ portion of the system. This study could not be carried out in the region above $\mathrm{ThO}_{2}-70 \mathrm{~m} / \mathrm{OUO}_{2}$ due to the instability of hyperstoichiometric solid solutions in this region of the system.

\section{THERMAL CYCLING STABILITY}

A study was made of the oxygenstability of hyperstoichiometric solid solutions during heating in air after sintering. Oxygen-uranium ratios were determined from weight-loss data by means of a thermogravimetric-balance technique. Equilibrium weight was determined at a series of temperatures in the range of 250 to $1250^{\circ} \mathrm{C}$. Uranium content was confirmed by chemical analysis of the materials before and after heating.

Two types of specimens were used in these determinations. One series was prepared by reaction-sintering of mixtures of $\mathrm{ThO}_{2}$ and $\mathrm{U}_{3} \mathrm{O}_{8}$. A second series was prepared by codigestion of uranyl nitrate and thorium nitrate. The nitrates were dissolved in water, evaporated to dryness, and calcined at $600^{\circ} \mathrm{C}$ for dissociation. All specimens were sintered in air at $1450^{\circ} \mathrm{C}$. The oxygen-uranium ratios following sintering were determined by calculation from the weight loss from hydrogen reduction at $1000^{\circ} \mathrm{C}$, and the uranium content was determined by chemical analysis.

After sintering at $1450^{\circ} \mathrm{C}$ in air, the $\mathrm{ThO}_{2}-70.4 \mathrm{~m} / \mathrm{oUO}_{2}$ composition, formed from the reaction of $\mathrm{U}_{3} \mathrm{O}_{8}$ and $\mathrm{ThO}_{2}$, had an oxygen-uranium ratio of 2.46. The equilibrium oxygen-uranium ratios obtained during thermal cycling of this composition in air are shown in Fig. 18. There was no change in oxygen content in the range of 250 to $400^{\circ} \mathrm{C}$ either during heating 
or cooling. Above $400^{\circ} \mathrm{C}$, the oxygen content varied with temperature in a nonlinear manner. The change in oxygen concentration was decidely less

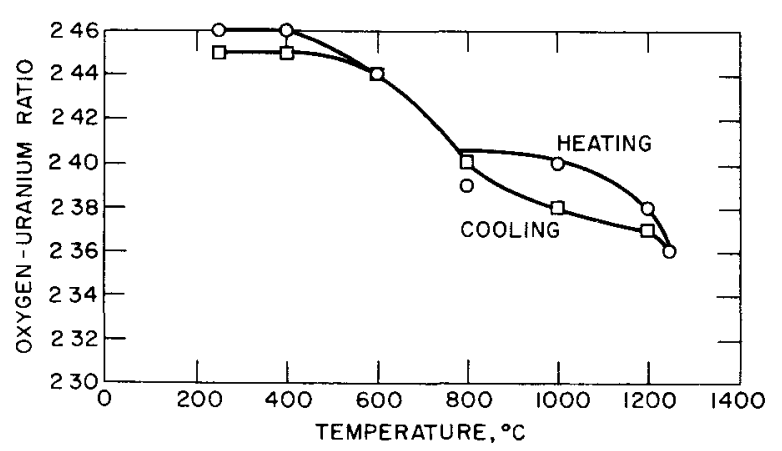

106-4607 Rev. 1

Fig. 18. Effect of Thermal Cycling on OxygenUranium Ratio of $\mathrm{ThO}_{2}-70.4 \mathrm{~m} / \mathrm{oUO}_{2}$ Formed from $\mathrm{ThO}_{2}-\mathrm{U}_{3} \mathrm{O}_{8}$ at $14500 \mathrm{C}$ in Air in the range of 800 to $1000^{\circ} \mathrm{C}$ than at temperatures above or below this range. The minimum oxygen-uranium ratio at $1250^{\circ} \mathrm{C}$ was 2.36. Higher temperatures were not used because of urania volatilization. The shape of the oxygen-gain curve, during cooling, was almost identical to the loss curve; however, the final oxygenuranium ratio (2.45) was slightly less than the initial value (2.46).

The same solid-solution composition $\left(\mathrm{ThO}_{2}-70.4 \mathrm{~m} / \mathrm{OUO}_{2}\right)$ was prepared in an identical manner except for the use of codigested nitrates

instead of oxides. After sintering at $1450^{\circ} \mathrm{C}$, the solid solution formed from codigested nitrates had a lower oxygen-uranium ratio (2.43) than the solid solution formed from the oxides $(\mathrm{O} / \mathrm{U}=2.46)$.

The results of thermal cycling on the codigested solid-solution material are shown in Fig. 19. Above $400^{\circ} \mathrm{C}$, the oxygen-uranium ratio decreased sharply from 2.43 to 2.38 at $800^{\circ} \mathrm{C}$. There was no change in the oxygen-uranium ratio in the range of 800 to $1200^{\circ} \mathrm{C}$, but at $1250^{\circ} \mathrm{C}$ there was a slight increase in this ratio. The equilibrium gain during cooling was greater than the loss on heating at all temperatures. After one cycle of heating and cooling in air, the speci-

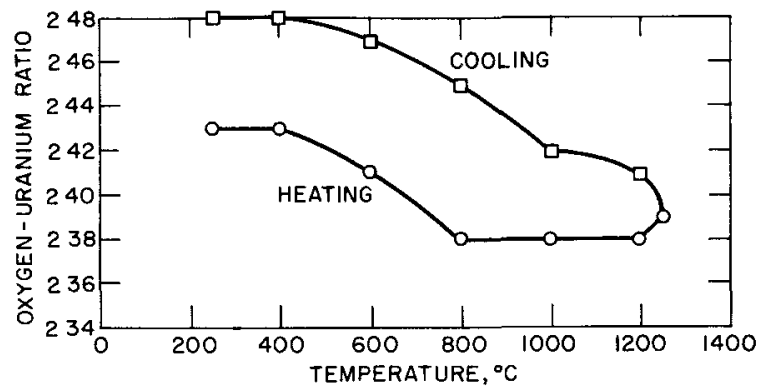

$106-4608$ Rev. 1

Fig. 19. Effect of Thermal Cycling on OxygenUranium Ratio of $\mathrm{ThO}_{2}-70.4 \mathrm{~m} / \mathrm{oUO}_{2}$ Formed from Codigested Nitrates men had an oxygen-uranium ratio of 2.48 as compared with a value of 2.43 before this treatment. There was no change during either cycle below $400^{\circ} \mathrm{C}$, and, above this temperature, the variation in the oxygen-uranium ratio appeared to occur in two distinct steps, the change taking place at 800 to $1000^{\circ} \mathrm{C}$.

The solid-solution composition $\mathrm{ThO}_{2}-30.5 \mathrm{~m} / \mathrm{oUO}_{2}$, formed from codigested nitrates, had an oxygen-uranium ratio of 2.52 after sintering in air at $1450^{\circ} \mathrm{C}$. When cycled in air, this material showed the characteristic change in the oxygen-uranium ratio curve at $800^{\circ} \mathrm{C}$ during both heating and cooling ( $F$ ig. 20). During cooling from $1250^{\circ} \mathrm{C}$, the oxygen-uranium ratios were consistently lower than those obtained during heating, and the final value was 2.48 . 


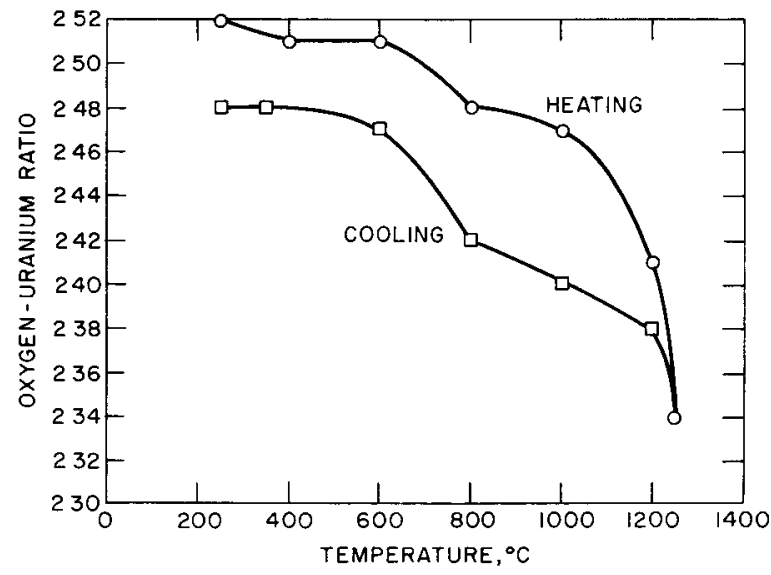

Figure 20

Effect of Thermal Cycling on Oxygen-Uranıum Ratio of $\mathrm{ThO}_{2}-30.5 \mathrm{~m} / \mathrm{oUO}_{2}$ Solid Solution Formed from Codigested Nitrates at $1450^{\circ} \mathrm{C}$

For the range of compositions and heat treatments studied, hyperstoichiometric $\mathrm{ThO}_{2}-\mathrm{UO}_{2}$ solid solutions were formed that had oxygenuranium ratios in the range of 2.43 to 2.52 . Thermal cycling of these materials to equilibrium weight in the temperature range of 250 to 1250 to $250^{\circ} \mathrm{C}$ resulted in minimum oxygen-uranium ratios of 2.34 to 2.38 (see Table VII).

TABLE VII Oxygen-Uranıum Ratıos of AIr-sıntered Solıd Solutions Reheated in Air

\begin{tabular}{|c|c|c|c|c|c|c|c|c|c|c|c|c|c|}
\hline \multirow{3}{*}{$\begin{array}{l}\text { Composition of } \\
\text { Solid Solution } \\
\mathrm{m} / \mathrm{o}\end{array}$} & \multicolumn{13}{|c|}{ Oxygen-Uranıum Ratio } \\
\hline & \multicolumn{7}{|c|}{ Heatıng. ${ }^{\circ} \mathrm{C}$} & \multicolumn{6}{|c|}{ Coolıng, ${ }^{\circ} \mathrm{C}$} \\
\hline & 250 & 400 & 600 & 800 & 1000 & 1200 & 1250 & 1200 & 1000 & 800 & 600 & 400 & 250 \\
\hline $\begin{array}{l}296 \mathrm{ThO}_{2}-704 \mathrm{UO}_{2} \text { from } \\
\mathrm{ThO}_{2}-\mathrm{U}_{3} \mathrm{O}_{8}\end{array}$ & 2.46 & 246 & 244 & 239 & 240 & 238 & 236 & 237 & 238 & 240 & 244 & 245 & 245 \\
\hline $\begin{array}{l}296 \mathrm{ThO}_{2}-704 \mathrm{UO}_{2} \text { from } \\
\text { Codigested Nitrates }\end{array}$ & 243 & 243 & 241 & 238 & 238 & 238 & 239 & 241 & 242 & 245 & 247 & 248 & 248 \\
\hline Codigested Nitrates & 252 & 251 & 251 & 2.48 & 247 & 241 & 234 & 238 & 240 & 242 & 247 & 248 & 2.48 \\
\hline
\end{tabular}

SIntered in air to $1450^{\circ} \mathrm{C}$

The samples used in this study were in the range of 93 to $95 \%$ of theoretical density and were pelletized to approximate average-sized fuel pellets. The irreversibility of the oxygen-uranium ratios may be due in part to the high-density compacts; however, all samples were held at constant weight for a minimum of $24 \mathrm{hr}$ before the temperature was changed. The increase of the oxygen-uranium ratio with thermal cycling is indicative of instability of the solid solution. No evidence of dissolution of the materials, to the extent of forming a two-phase system, was found by $\mathrm{X}-\mathrm{ray}$ or microscopic examination. 


\section{OXIDATION CHARACTERISTICS}

The effects of the method of preparation and the sintering temperature on the stability of $\mathrm{ThO}_{2}-\mathrm{UO}_{2}$ solid solutions was determined for a wide range of compositions. Materials were prepared by sintering $\mathrm{ThO}_{2}-\mathrm{U}_{3} \mathrm{O}_{8}$ mixtures in air and $\mathrm{ThO}_{2}-\mathrm{UO}_{2}$ mixtures in hydrogen in the range of 1200 to $1650^{\circ} \mathrm{C}$. Sintered samples were crushed to minus $200 \mathrm{mesh}$, reduced to stoichiometry in hydrogen, and reoxidized by heating for $48 \mathrm{hr}$ in static air. Oxygen-metal atom ratios were used as the basis for evaluation and these were calculated from weight changes occurring during oxidation. Reduction of the powders to stoichiometry was assumed as a basis for determination of uranium content.

The results of the reoxidation of $1200^{\circ} \mathrm{C}$ air-sintered solid solutions are shown in Fig. 21 . The oxygen-metal atom ratios for all materials increased rapidly to a maximum value for the $400^{\circ} \mathrm{C}$ oxidation treatment. In most cases, this value was approximately the same as the ratio resulting from sintering of the materials in air. The $\mathrm{ThO}_{2}-90 \mathrm{~m} / \mathrm{OUO}_{2}$ composition was a two-phase system as indicated by the high oxygen-metal atom

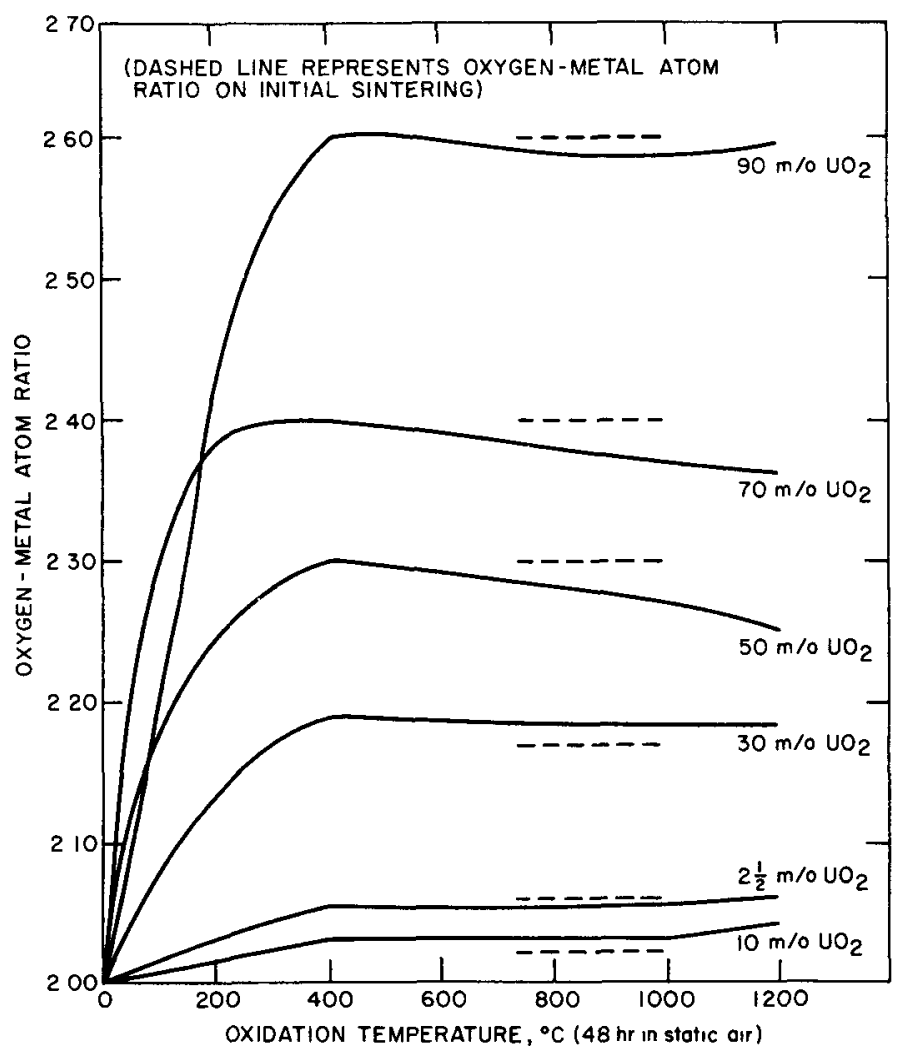

106-6301 Rev. 1

Fig. 21. Reoxidation Characteristics of Solid Solutions Initially Formed from $\mathrm{ThO}_{2}-\mathrm{U}_{3} \mathrm{O}_{8}$ Sintered in Air at $1200^{\circ} \mathrm{C}$ for 18 hours ratio. Compositions containing greater than $30 \mathrm{~m} / \mathrm{O} \mathrm{UO}_{2}$ showed a tendency for a decreasing oxygen-metal atom ratio at temperatures above $400^{\circ} \mathrm{C}$. Compositions in this range tended to resinter during the oxidation treatments at $800^{\circ} \mathrm{C}$ and above, and the resulting decrease in surface area may have contributed to the lower oxygen-metal atom ratios.

Air-sintered samples formed at higher temperatures were reoxidized in the same manner, the results being shown in Fig. 22. The ultimate oxygenmetal atom ratios after reoxidation were approximately the same as those resulting from sintering in air. The difference in oxidation characteristics to be noted was that the samples sintered at high temperatures showed very little oxidation on reheating to $200^{\circ} \mathrm{C}$ in air. The 


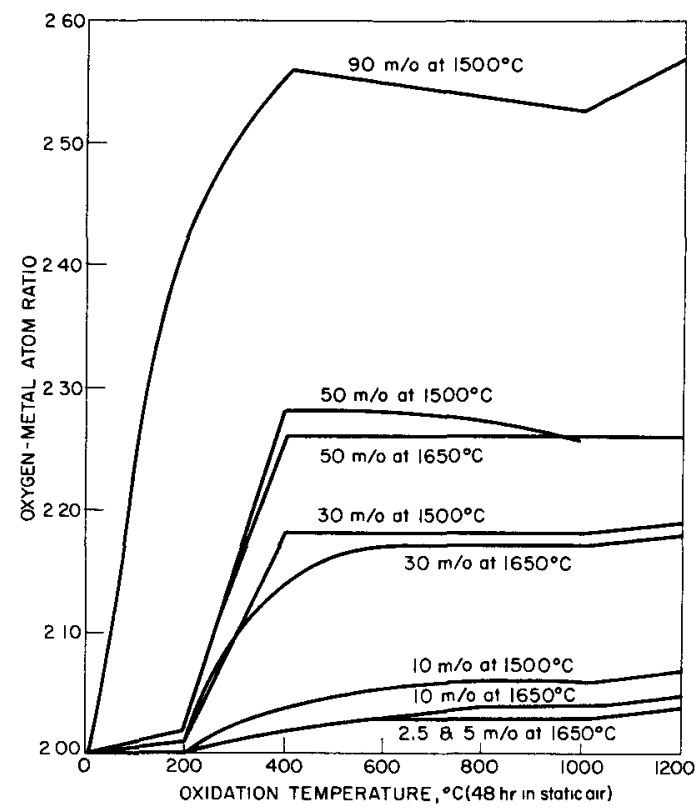

106-6297 Rev. 1

Fig. 22. Reoxidation Characteristics of $\mathrm{ThO}_{2}-\mathrm{U}_{3} \mathrm{O}_{8}$ Solid Solutions Sintered in Air for 18 hours temperature at which the maximum oxygen-metal atom ratio occurred, during reoxidation, decreased from $800^{\circ} \mathrm{C}$ for low-urania concentrations to $400^{\circ} \mathrm{C}$ for high-urania concentrations. This behavior indicates a greater resistance to oxidation for solid solutions containing $10 \mathrm{~m} / \mathrm{o}$ of $\mathrm{UO}_{2}$ or less.

The oxidation characteristics of hydrogen-sintered $\mathrm{ThO}_{2}-\mathrm{UO}_{2}$ solid solutions are shown in Fig. 23. Solid solutions formed by sintering at $1200^{\circ} \mathrm{C}$ in hydrogen oxidized to a greater degree than did equivalent air-sintered materials. Solid solutions formed above $1200^{\circ} \mathrm{C}$ in hydrogen tended to reach their maximum oxidation at a lower temperature $\left(400^{\circ} \mathrm{C}\right)$ than did the equivalent airsintered materials. The ultimate

oxygen-metal atom ratios were approximately the same for both cases. An increased resistance to oxidation was

shown for the higher $\mathrm{UO}_{2}$ concentrations that had been sintered in hydrogen. The $90 \mathrm{~m} / \mathrm{O}_{2}$ material was single-phase in the case of hydrogen sintering.

Stoichiometric materials that had been prepared by sintering in hydrogen were further investigated by differential thermal analysis. Fine powders of these solid solutions were heated in static air at a rate of $10^{\circ} \mathrm{C} /$ min between 100 and $1200^{\circ} \mathrm{C}$.

The peaks of the oxidation reaction (Fig. 24) do not correlate exactly with the previous data. The differences are probably due to test conditions since the DTA sample is small and loosely-packed so that air may circulate through the sample.

There were no measurable thermal effects for the $\mathrm{ThO}_{2}-2.5 \mathrm{~m} / \mathrm{O}$ $\mathrm{UO}_{2}$ and $\mathrm{ThO}_{2}-5 \mathrm{~m} / \mathrm{OUO}_{2}$. The first effect noted was for the $\mathrm{ThO}_{2}-10 \mathrm{~m} / \mathrm{o}$ $\mathrm{UO}_{2}$ composition, which exhibited a small, exothermic plateau between

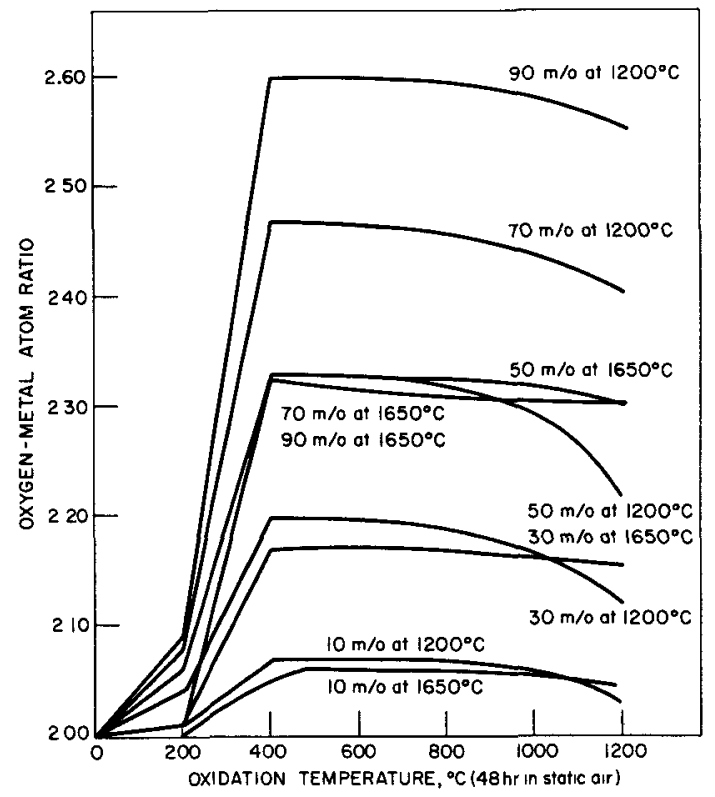

106-6295 Rev. 1

Fig. 23. Oxidation Characteristics of Stoichiometric $\mathrm{ThO}_{2}-\mathrm{UO}_{2}$ Solid Solutions Sintered in Hydrogen for 18 hours 
350 and $650^{\circ} \mathrm{C}$. As the concentration of $\mathrm{UO}_{2}$ in the solid solution was increased, the oxidation peaks became more intense and shifted toward $350^{\circ} \mathrm{C}$. The oxidation peaks for the higher $\mathrm{UO}_{2}$ concentrations correlated well with the peak for the oxidation reaction $\mathrm{UO}_{2} \rightarrow \mathrm{U}_{3} \mathrm{O}_{8} .{ }^{14}$

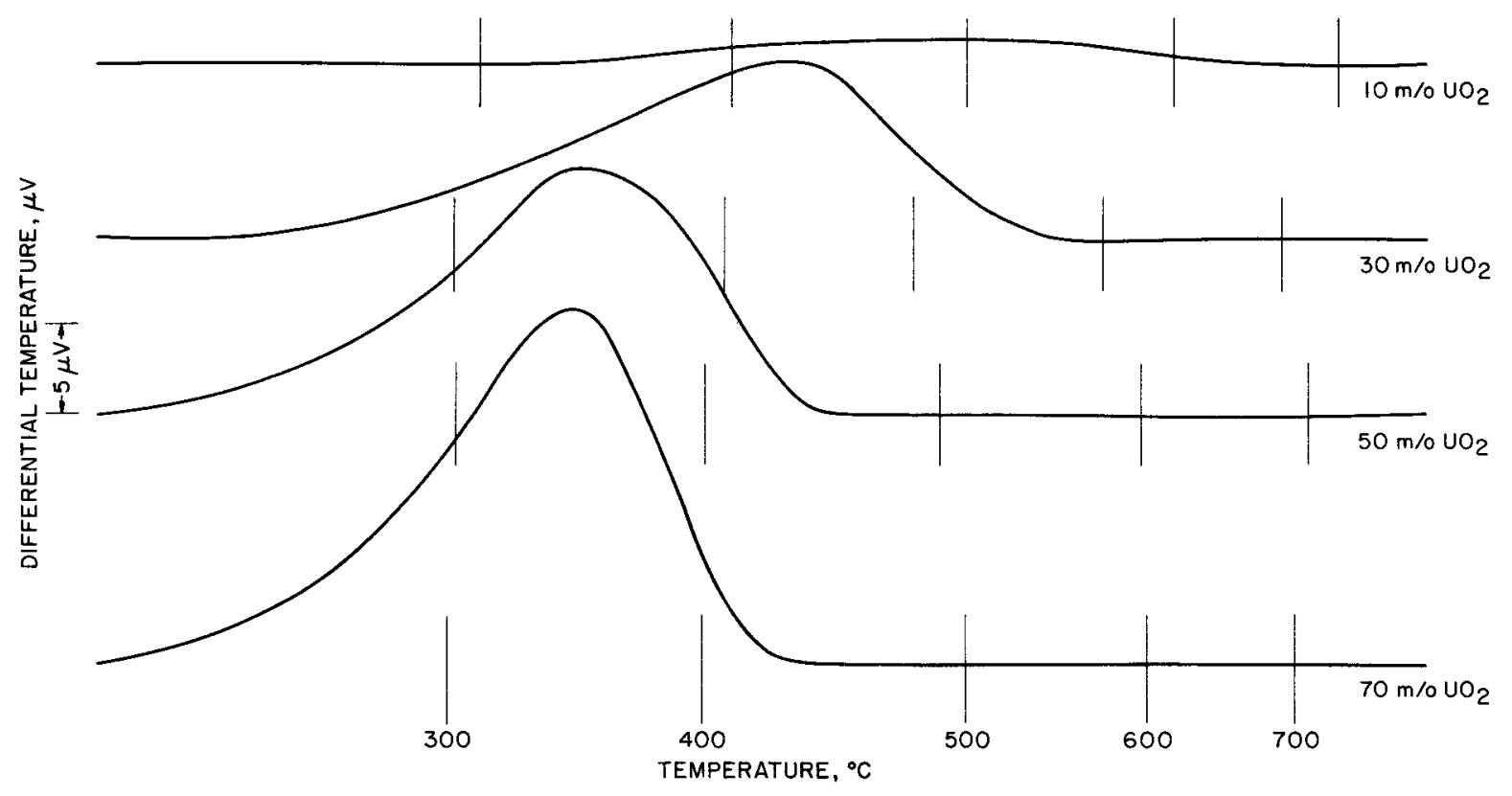

Fig. 24. Oxidation Peaks (DTA) for Stoichiometric $\mathrm{ThO}_{2}-\mathrm{UO}_{2}$ Solid Solutions

\section{EFFECTS OF STOICHIOMETRY ON DIMENSIONAL STABILITY}

Some results obtained in the densification study of hyperstoichiometric $\mathrm{ThO}_{2}-\mathrm{UO}_{2}$ solid solutions indicated that dimensional changes were associated with the change in stoichiometry during sintering. To evaluate this effect, the length changes occurring during the heating of hyperstoichiometric and stoichiometric solid solutions were measured.

Length change during heating was measured by a dilatometric technique. Heating was carried out in a stepwise fashion, each temperature being held constant until no further change in length was noted. For ease of operation, a vacuum was used instead of hydrogen to reduce the stoichiometry during the heating process. Samples of greater than $90 \%$ theoretical density were prepared by sintering in both hydrogen and air to produce variable-stoichiometry samples.

The results obtained from heating hyperstoichiometric and stoichiometric $\mathrm{ThO}_{2}-2.5 \mathrm{~m} / \mathrm{oUO}_{2}$ solid solutions in vacuo are shown in Fig. 25. Heating of the hyperstoichiometric solid solution resulted in an expansion to about $1250^{\circ} \mathrm{C}$ and shrinkage above this temperature. The expansion curve 


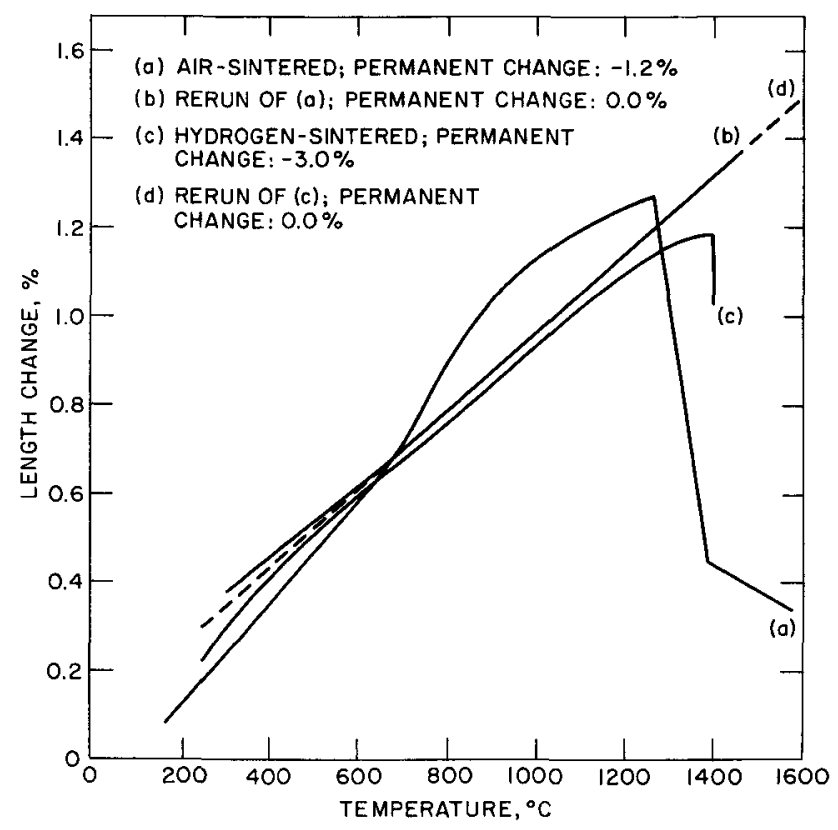

106-6300 Rev. 1

Fig. 25. Dimensional Stability of a $\mathrm{ThO}_{2}-2.5 \mathrm{~m} / \mathrm{oUO}_{2}$ Solid Solution Heated in Vacuo $\left(10^{-5}\right.$ Torr), Sintered at $1500^{\circ} \mathrm{C}$ showed definite rate changes at approximately 700,1000 , and $1250^{\circ} \mathrm{C}$. When cooled to room temperature, the sample showed a permanent shrinkage of $1.2 \%$ in length. The changes in rate of expansion at approximately 700 and $1000^{\circ} \mathrm{C}$ are apparently as sociated with stoichiometry adjustment. The shrinkage at higher temperatures appeared to be sintering of the sample.

The stoichiometric sample of the same composition had a uniform expansion, at a consider ably lower rate, to approximately $1300^{\circ} \mathrm{C}$. Above this temperature a shrinkage occurred, due to sintering, which resulted in a permanent 3\% decrease in length. When both samples were rerun under the same heating condi-

tions, the expansion curves were practically superimposed, and there was no further permanent dimensional change.

Additional samples of the $\mathrm{ThO}_{2}-2.5 \mathrm{~m} / \mathrm{oUO} 2$ composition were prepared by sintering at $1650^{\circ} \mathrm{C}$ to minimize the shrinkage effect noted previously. The data for both stoichiometric and hyperstoichiometric materials, shown in Fig. 26, were nearly identical over the entire temperature range, and there was no permanent change in dimensions. There was no apparent increase in rate-of-length change due to stoichiometry change for these materials. The oxygen-metal atom ratio was initially lower (2.03) for the material sintered at $1650^{\circ} \mathrm{C}$ than it was (2.06) for the material sintered at $1500^{\circ} \mathrm{C}$.

Since previous tests had shown permanent shrinkage to

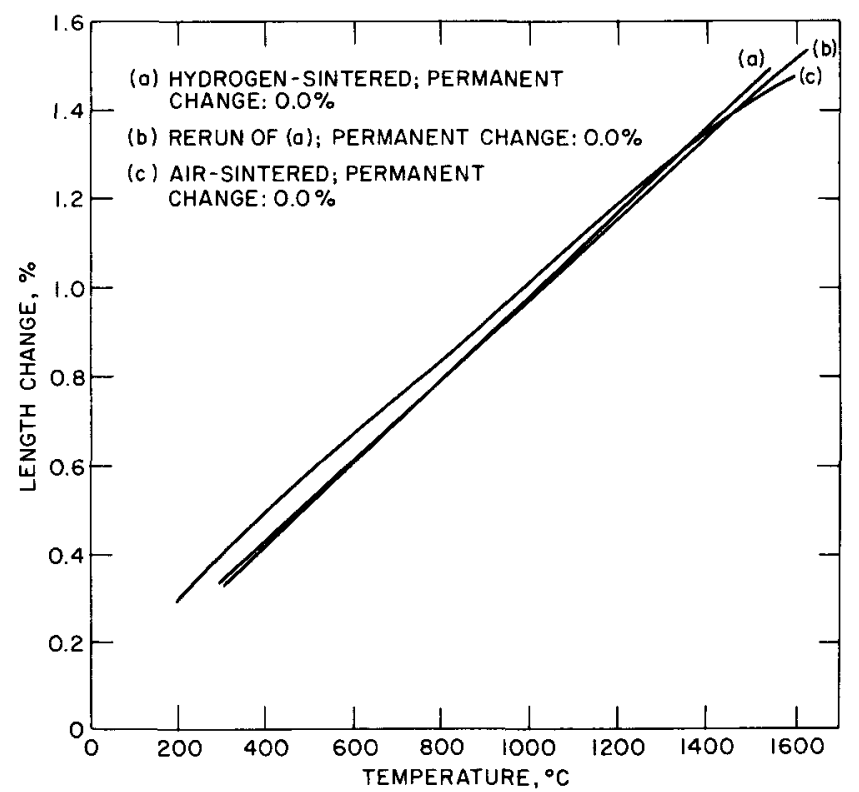

106-6303 Rev. 1

Fig. 26. Dimensional Stability of a $\mathrm{ThO}_{2}$ $2.5 \mathrm{~m} / \mathrm{oUO}_{2}$ Solid Solution Heated in Vacuo $\left(10^{-5}\right.$ Torr $)$, Sintered at $\overline{1650^{\circ} \mathrm{C}}$ 
occur, as a result of sintering during reheating in vacuo, further measurements on higher-urania solid solutions were stopped when sintering was

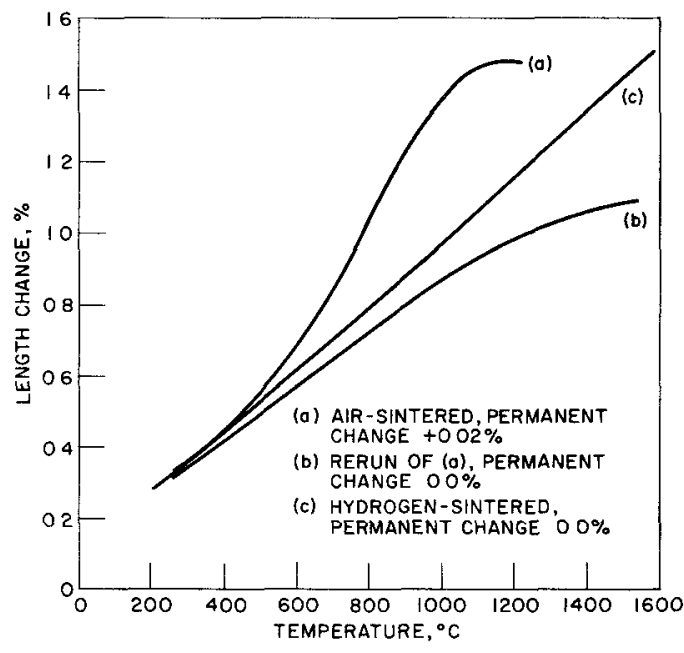

106-6294 Rev. 1

Fig. 27. Dimensional Change of a $\mathrm{ThO}_{2}-$ $10 \mathrm{~m} / \mathrm{oUO}_{2}$ Solid Solution Heated in Vacuo $\left(10^{-5}\right.$ Torr $)$, Sintered at $1650^{\circ} \mathrm{C}$ indicated. At the first indication of shrinkage, the sample was quenched in vacuo, measured, and the experiment was repeated.

The results of reheating $\mathrm{ThO}_{2}-$ $10 \mathrm{~m} / \mathrm{oUO}_{2}$ solid solutions are shown in Fig. 27. The rate of expansion, for the hyperstoichiometric solid solution, was very rapid to about $1200^{\circ} \mathrm{C}$ where the sudden change in rate indicated sintering. The sample, when cooled from this temperature, had a permanent expansion of $0.02 \%$. This expansion was of the same order as the accuracy of measurement, but it was the first indication that a permanent expansion might occur. A rerun of this material resulted in a uniform expansion, at a considerably decreased rate, to approximately $1350^{\circ} \mathrm{C}$, where the sample appeared to be sinter-

ing. The stoichiometric solid solution exhibited a uniform expansion rate, and there was no measurable, permanent, dimensional change.

Compositions of $\mathrm{ThO}_{2}-30 \mathrm{~m} / \mathrm{oUO}_{2}$ showed a similar but more exaggerated expansion when heated in vacuo (Fig. 28). The initial heating of hyperstoichiometric material in vacuo to $1200^{\circ} \mathrm{C}$ showed a very rapid change in expansion at about $700^{\circ} \mathrm{C}$. The heating of this material to $1200^{\circ} \mathrm{C}$ resulted in a permanent expansion of $0.29 \%$. The rerun of this material produced a uniform expansion curve, and no permanent change in dimensions was found. The materials prepared initially as stoichiometric $\mathrm{ThO}_{2}-30 \mathrm{~m} / \mathrm{OUO}_{2}$ exhibited a uniform expansion curve at a rate approximately the same as that for the rerun of initially hyperstoichiometric material. The material that was stoichiometric initially showed no permanent change in dimensions.

Hyperstoichiometric solid solutions of $\mathrm{ThO}_{2}-50 \mathrm{~m} / \mathrm{oUO}_{2}$ and $\mathrm{ThO}_{2}-70 \mathrm{~m} / \mathrm{o}$ $\mathrm{UO}_{2}$ showed a tendency to react with the

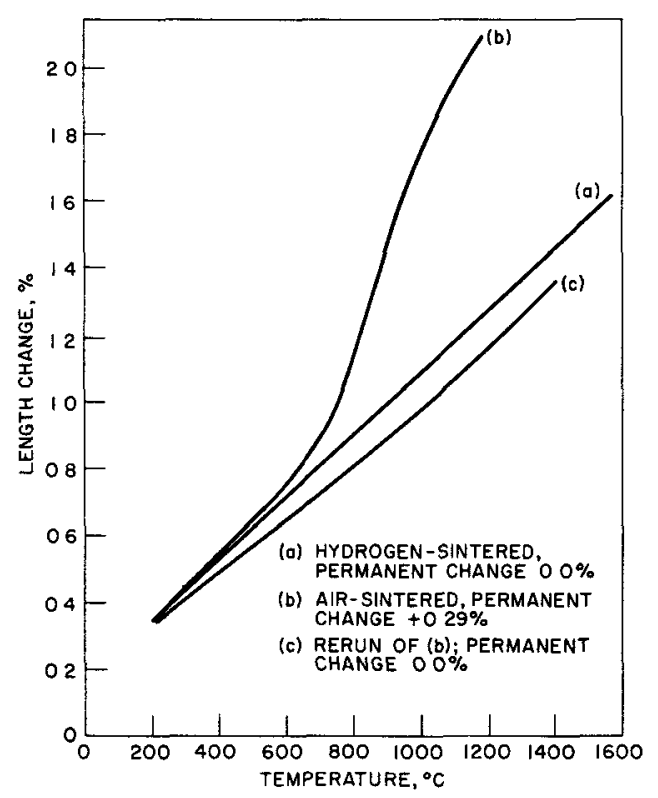

106-6304 Rev. 1

Fig. 28. Dimensional Stability of a $\mathrm{ThO}_{2}$ $30 \mathrm{~m} / \mathrm{O} \mathrm{UO}_{2}$ Solid Solution Heated in Vacuo $\left(10^{-5}\right.$ Torr $)$, Sintered at $1650^{\circ} \mathrm{C}$ 


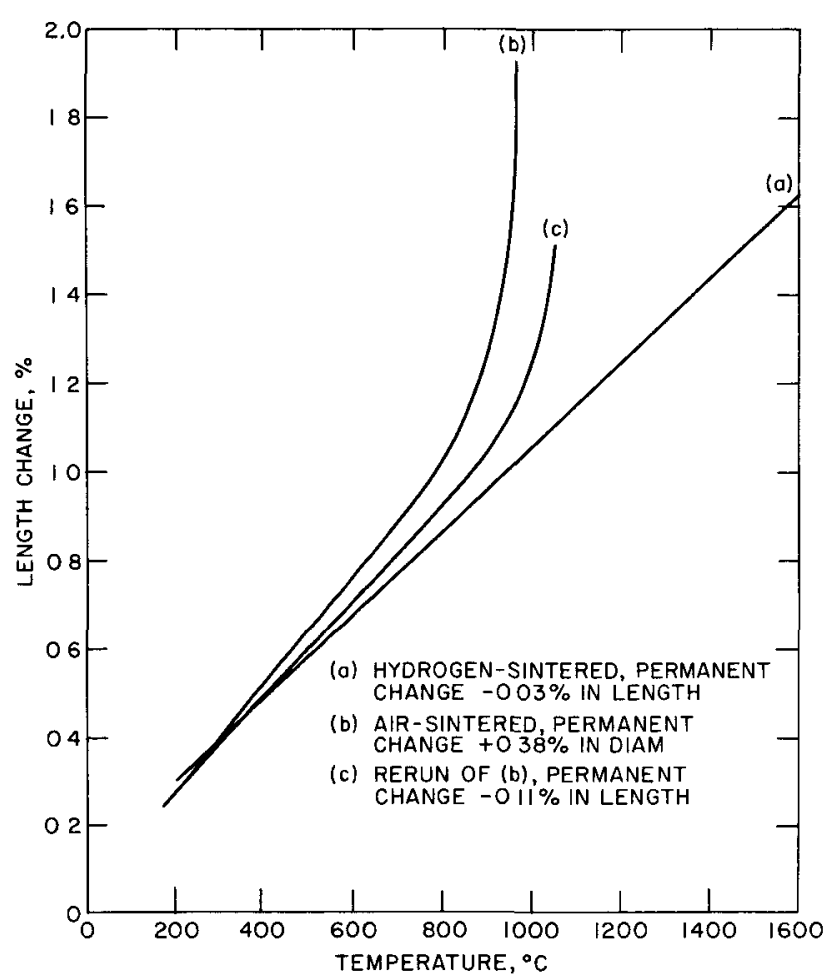

106-6296 Rev. 1

Fig. 29. Dimensional Stability of a $\mathrm{ThO}_{2}-50 \mathrm{~m} / \mathrm{oUO}_{2}$ Solid Solution Heated in Vacuo $\left(10^{-5}\right.$ Torr $)$, Sintered at $1650^{\circ} \mathrm{C}$ tantalum push rod of the dilatometer. The reaction was apparently oxidation of the tantalum by oxygen released during the reduction to stoichiometry. The stoichiometric solid solutions of the same compositions had no such reactions, and the expansion curves showed no irregularities.

The results from determinations on $\mathrm{ThO}_{2}-50 \mathrm{~m} / \mathrm{oUO}_{2}$ compositions are shown in Fig. 29. The expansion curve for the stoichiometric solid solution of this composition was linear throughout the temperature range of testing. During the first run of the hyperstoichiometric material, a very rapid increase in length was found at about $800^{\circ} \mathrm{C}$. This change of rate showed no tendency to slow down after $l \mathrm{hr}$ at temperature; therefore the sample was quenched. Reaction had occurred between the sample and the tantalum support. The material showed no permanent change in diameter, and the permanent decrease of length was probably due to the reaction. When the sample was reheated in vacuo, the rapid increase in rate began about $50^{\circ} \mathrm{C}$ higher than on the first run. Examination of the sample showed severe reaction with the tantalum tooling, and no further determinations were made. After the second cycle, the $\mathrm{ThO}_{2}-50 \mathrm{~m} / \mathrm{oUO}_{2}$ composition showed a $0.38 \%$ increase in diameter, thus following the same trend as the previous materials. The apparent shrinkage of length of the sample was due to the reaction with tantalum.

Compositions containing more than $50 \mathrm{~m} / \mathrm{o} \mathrm{UO}_{2}$ were not used in these determinations because of their reaction with tantalum during reduction to stoichiometry.

The dilatometer apparatus was limited to operation only in vacuo; therefore oxygen could not be introduced into the system to follow the effects of oxidation on dimensional change. Some further work was done by means of an interferometric method of determining length changes at elevated temperatures, because this apparatus was adaptable to operation in vacuo or in an atmosphere of air. The upper temperature limit for this apparatus was approximately $900^{\circ} \mathrm{C}$. A heating rate of $5^{\circ} \mathrm{C} / \mathrm{min}$ was used for the expansion determinations. 
Thermal expansions were determined for $\mathrm{UO}_{2}, \mathrm{ThO}_{2}$, and stoichiometric solid solutions in the compositional range of $\mathrm{ThO}_{2}-2.5 \mathrm{~m} / \mathrm{oUO}_{2}$ to

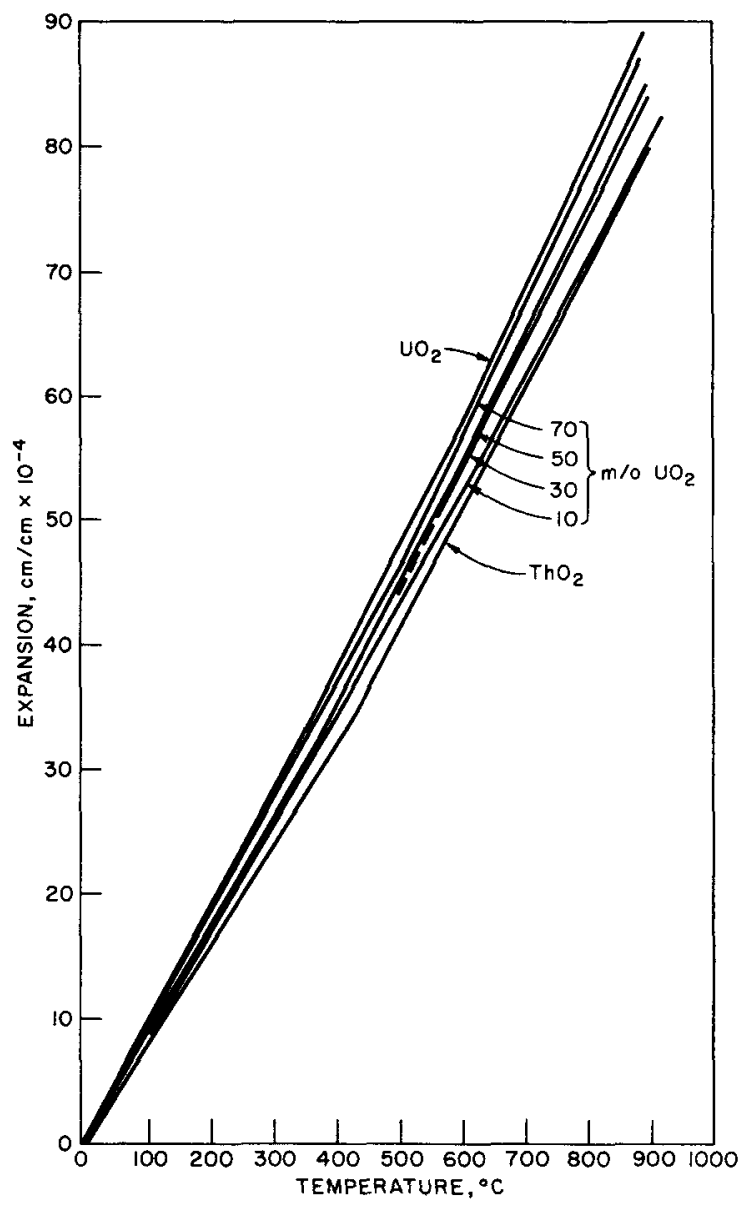

Fig. 30. Thermal Expansion of Stoichiometric ThoriaUrania Solid Solutions (determined in vacuo) $\mathrm{ThO}_{2}-70 \mathrm{~m} / \mathrm{oUO}_{2}$. Samples for these determinations were prepared by reaction-sintering $\mathrm{ThO}_{2}-\mathrm{UO}_{2}$ compacts in hydrogen at $1650^{\circ} \mathrm{C}$, followed by reheating to $1500^{\circ} \mathrm{C}$ in vacuo. The second heating step in vacuo was used to insure stoichiometry and to reproduce conditions of the previous experiments

The thermal-expansion curves for stoichiometric materials are shown in Fig. 30, and the calculated coefficients of expansion are shown in Table VIII. The thermal-expansion curves for the stoichiometric materials showed no abrupt changes in rate for the determinations made in vacuo. There was a gradual, but not uniform, increase in expansion coefficient as the $\mathrm{UO}_{2}$ content of the solid solution was increased.

The effects of oxidation on the expansion of stoichiometric solid solutions were determined by measuring the expansion in an atmosphere of static air. The results are shown in Fig. 31 and Table VIII. The $\mathrm{ThO}_{2-}$ $2.5 \mathrm{~m} / \mathrm{OUO}_{2}$ composition showed no sudden change in expansion during heating, although the rate increased considerably above $400^{\circ} \mathrm{C}$. For compositions containing higher $\mathrm{UO}_{2}$ contents, rapid increases in expansion rates occurred in the range of 300 to $500^{\circ} \mathrm{C}$. In the case of the $\mathrm{ThO}_{2}-70 \mathrm{~m} / \mathrm{oUO}_{2}$ composition, the rate of expansion became too rapid to follow with the interferometer apparatus. These rapid rates of expansion were apparently associated with oxidation since the temperature range was the same as that at which oxidation has been shown to occur. The first effect noted was an apparent relaxation followed by a rapid increase in rate of expansion. Increased $\mathrm{UO}_{2}$ content appeared to correlate with greater increases in rate following the relaxation. A shrinkage or relaxation of the expansion might be expected to occur as a result of lattice shrinkage during oxidation.

Hyperstoichiometric solid solutions for expansion determination were prepared by reaction-sintering $\mathrm{ThO}_{2}-\mathrm{U}_{3} \mathrm{O}_{8}$ mixtures in air. The results of expansion determinations for these materials, heated in static air, are shown in Fig. 32 and Table VIII. 
TABLE VIII Calculated Coefficients of Expansion for Thoria-Uranıa Solıd Solutions

\begin{tabular}{|c|c|c|c|c|c|c|c|}
\hline \multirow{2}{*}{$\begin{array}{c}\text { Temp } \\
\text { Range, } \\
{ }^{\circ} \mathrm{C}\end{array}$} & \multicolumn{7}{|c|}{ Coefficient of Thermal Expansion, $\alpha \times 10^{-6}$} \\
\hline & $\mathrm{ThO}_{2}$ & $2.5 \mathrm{~m} / \mathrm{o} \mathrm{UO}_{2}$ & $10 \mathrm{~m} / \mathrm{O} \mathrm{UO}_{2}$ & $30 \mathrm{~m} / \mathrm{O} \mathrm{UO}_{2}$ & $50 \mathrm{~m} / \mathrm{OUO}_{2}$ & $70 \mathrm{~m} / \mathrm{o} \mathrm{UO}_{2}$ & $\mathrm{UO}_{2}$ \\
\hline \multicolumn{8}{|c|}{ A } \\
\hline $0-300$ & 8.0 & 8.4 & 8.6 & 8.9 & 86 & 9.2 & 94 \\
\hline $0-600$ & 8.4 & 8.6 & 8.7 & 9.0 & 9.1 & 9.4 & 9.6 \\
\hline $0-900$ & 9.0 & 8.9 & - & 9.6 & 9.5 & 9.9 & 100 \\
\hline \multicolumn{8}{|c|}{ B Stoichiometric Solid Solutions, Determined in Air } \\
\hline $24-300$ & - & 8.5 & 8.6 & 8.7 & 8.4 & 89 & - \\
\hline $24-600$ & - & 8.9 & 9.4 & 8.8 & 10.1 & 11.7 & - \\
\hline $24-900$ & - & 9.2 & 96 & 9.2 & 12.2 & - & - \\
\hline \multicolumn{8}{|c|}{ C Hyperstoichiometric Solid Solutions, Determined in Air } \\
\hline $24-300$ & - & - & 9.0 & 8.7 & 8.7 & 8.4 & - \\
\hline $24-600$ & - & - & 9.6 & 9.8 & 105 & 10.0 & - \\
\hline $24-900$ & - & - & 101 & 9.3 & - & 9.4 & - \\
\hline
\end{tabular}

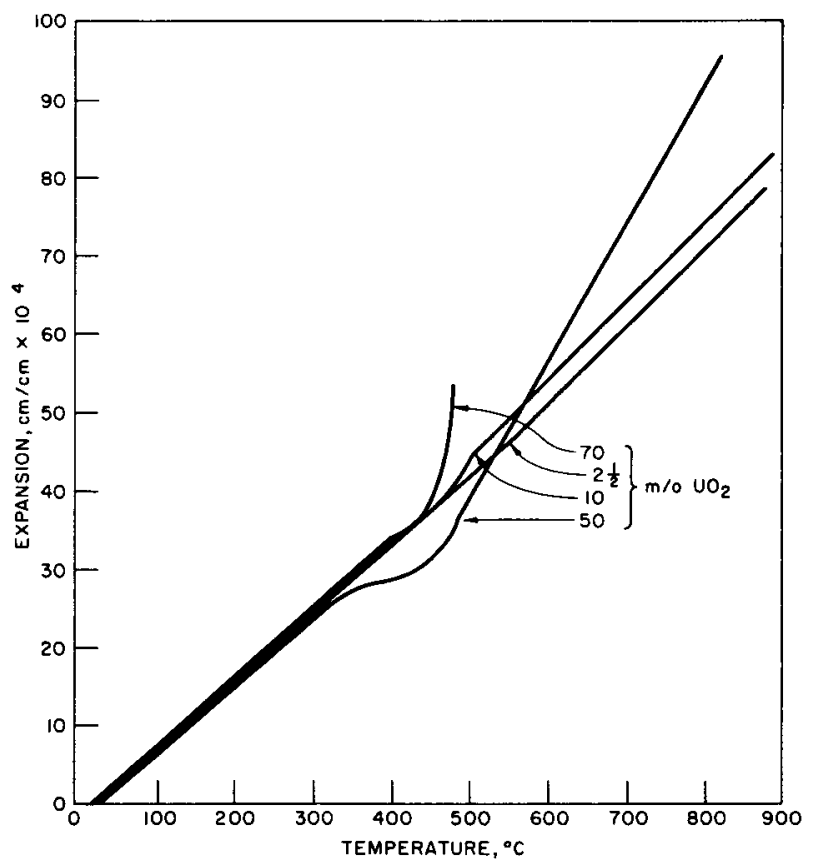

Fig. 31. Thermal Expansion of Stoichometric Thorıa-Urania Solid Solutions (determined in aır)

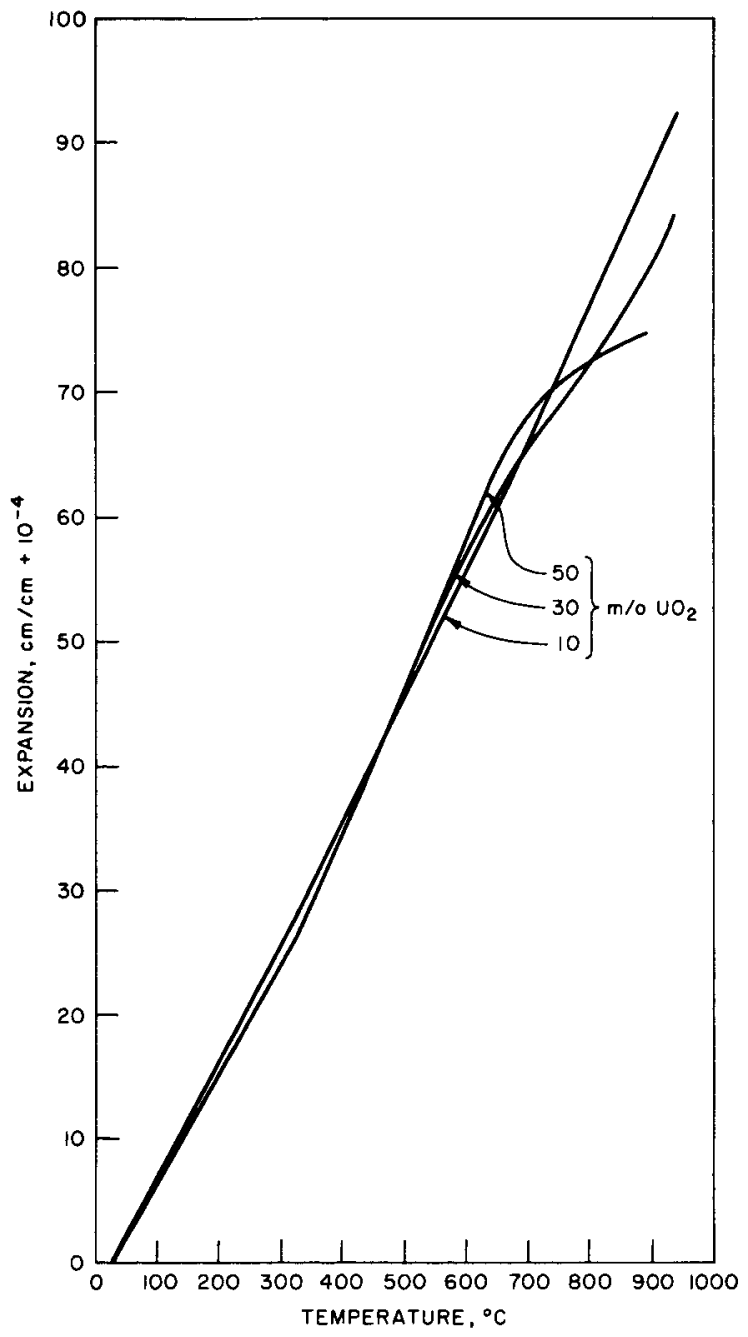

Fig. 32. Thermal Expansion of Hyperstolchiometric Thorıa-Uranıa Solıd Solutions (determined in air) 
These materials exhibited a fairly uniform expansion rate below $600^{\circ} \mathrm{C}$. The solid solutions containing $10 \mathrm{~m} / \mathrm{o} \mathrm{UO}$, or less, had gradually increasing rates of expansion to $900^{\circ} \mathrm{C}$. For higher $\mathrm{UO}_{2}$ contents, there was a tendency for a decreased expansion rate above $600^{\circ} \mathrm{C}$. This change in rate occurred in the same temperature range in which a decreasing oxygen-metal atom ratio was found to occur during heating of hyperstoichiometric solid solutions in air. 


\section{NEUTRON-DIFFRACTION STUDY}

It has been reported that a cubic phase is obtained upon heating $\mathrm{U}_{3} \mathrm{O}_{8}$ with $\mathrm{ThO}_{2}$, Ref. 10. In the intermediate-composition ranges, two "cubic" diffraction patterns are observed, one of which has a lattice parameter smaller than that obtained from a corresponding composition of $\mathrm{ThO}_{2}-\mathrm{UO}_{2}$ that has been sintered in a hydrogen atmosphere. It is reasonable to suppose that in the $\mathrm{ThO}_{2}-\mathrm{U}_{3} \mathrm{O}_{8}$ compositions $\mathrm{U}^{+6}$ ions are present as well as excess oxygen, in terms of $\mathrm{ThO}_{2}-\mathrm{UO}_{2}$ compositions. It was therefore of interest to determine if the "cubic" phase with smaller lattice parameter consists of a fluorite structure with essentially all oxygen sites occupied, but with a deficiency of metal ions in other sites, which might account for the decreased lattice parameter.

This investigation was originated and carried out by $\mathrm{M}$. H. Mueller, ANL. Two samples were supplied for neutron diffraction: one sample of $\mathrm{ThO}_{2}-50 \mathrm{~m} / \mathrm{OUO}_{2}$ sintered in hydrogen at $1650^{\circ} \mathrm{C}$ for $15 \mathrm{hr}$, and another sample of $\mathrm{ThO}_{2}-\mathrm{U}_{3} \mathrm{O}_{8}$ prepared with equal molar concentrations of uranium and thorium and sintered in air at $1450^{\circ} \mathrm{C}$ for $90 \mathrm{hr}$. The X-ray diffraction patterns of the two materials showed a single "cubic" phase for the $\mathrm{ThO}_{2}-\mathrm{UO}_{2}$ material and two "cubic" patterns in the $\mathrm{ThO}_{2}-\mathrm{U}_{3} \mathrm{O}_{8}$ sample. The strongest "cubic" pattern from the latter material has a lattice parameter considerably smaller than that observed in the $\mathrm{ThO}_{2}-\mathrm{UO}_{2}$ material, and the other very weak pattern has a lattice parameter more nearly the same as the $\mathrm{ThO}_{2}-\mathrm{UO}_{2}$.

If the composition of this material is written as ( $\mathrm{U}, \mathrm{ThO})_{1-\mathrm{x}} \mathrm{O}_{2}$, where $\mathrm{x}=0$ for the $\mathrm{ThO}_{2}-\mathrm{UO}_{2}$, and if it is assumed that $\mathrm{x}=0.15$ for the $\mathrm{ThO}_{2}-\mathrm{U}_{3} \mathrm{O}_{8}$ sample, then the calculated intensities for the first three peaks in a neutrondiffraction pattern are considerably different for the two samples, as indicated in Table IX.

TABLE IX. Comparison of Calculated and Observed Relative Intensities for $\mathrm{ThO}_{2}-\mathrm{UO}_{2}$ and $\mathrm{ThO}_{2}-\mathrm{U}_{3} \mathrm{O}_{8}$

\begin{tabular}{|c|c|c|c|c|}
\hline \multirow{2}{*}{$\begin{array}{c}\text { Lattice } \\
\text { Direction }\end{array}$} & \multicolumn{2}{|c|}{$\mathrm{ThO}_{2}-\mathrm{UO}_{2}$} & \multicolumn{2}{c|}{$\mathrm{ThO}_{2}-\mathrm{U}_{3} \mathrm{O}_{8}$} \\
\cline { 2 - 5 } & Calculated & Observed & Calculated & Observed \\
\hline 111 & 34.1 & 36.8 & 28.3 & 32.5 \\
200 & 3.2 & 1.4 & 9.5 & - \\
220 & 100.0 & 100.0 & 100.0 & 100.0 \\
\hline
\end{tabular}

There is better agreement between calculated and observed intensities for the $\mathrm{ThO}_{2}-\mathrm{UO}_{2}$ than for the $\mathrm{ThO}_{2}-\mathrm{U}_{3} \mathrm{O}_{8}$. The neutron pattern for the $\mathrm{ThO}_{2}-\mathrm{U}_{3} \mathrm{O}_{8}$ sample was similar to that obtained for $\mathrm{UO}_{2}+\mathrm{x}$ type material, where $\mathrm{x}$ is approximately 0.25 to 0.33 . 
Solid solutions in the $\mathrm{ThO}_{2}-\mathrm{UO}_{2}$ system were formed by heating, in air, mixtures composed of $\mathrm{ThO}_{2}-\mathrm{U}_{3} \mathrm{O}_{8}$ or the decomposition product of codigested uranyl nitrate and thorium nitrate. In either case, the solid solutions formed were hyperstoichiometric, and the extent of departure from stoichiometry was dependent on the reaction-sintering temperature, time, composition, and cooling rate.

In $\mathrm{ThO}_{2}-\mathrm{U}_{3} \mathrm{O}_{8}$ mixtures, solid solution was apparent at $1000^{\circ} \mathrm{C}$, and complete solid solution was formed above $1250^{\circ} \mathrm{C}$. Heat treatment above $1250^{\circ} \mathrm{C}$ was necessary to yield high-density products from compacts of these materials.

The loss of oxygen from $\mathrm{U}_{3} \mathrm{O}_{8}$ was accelerated by thoria. In mixtures of the two oxides, $\mathrm{U}_{3} \mathrm{O}_{8}$ lost weight at an appreciable rate at temperatures 200 to $600^{\circ} \mathrm{C}$ below that required for the first evidence of solidsolution formation by X-ray analysis. Differential-thermal-analysis (DTA) curves showed the solid-solution reaction to begin immediately after an endothermic peak in $\mathrm{U}_{3} \mathrm{O}_{8}$ that occurred at about $920^{\circ} \mathrm{C}$.

Densification studies of air-sintered solid solutions indicated a maximum density change for compositions in the range of $\mathrm{ThO}_{2}-5 \mathrm{~m} / \mathrm{OUO}_{2}$ to $\mathrm{ThO}_{2}-10 \mathrm{~m} / \mathrm{oUO}_{2}$. Lower sintering temperatures resulted in densities below the original pressed-density for high- $\mathrm{UO}_{2}$ compositions, and this effect apparently was related to oxygen loss from the solid solutions.

In general, the densification of hydrogen-sintered materials was influenced more by temperature change than by composition. This result indicates further the relationship of stoichiometry to densification. Stoichiometric solid solutions, formed by sintering in hydrogen, exhibited greater density changes and higher bulk densities than did the hyperstoichiometric materials.

The extent of hyperstoichiometry in the air-sintered materials was reproducible if the same composition and sintering temperature were used. Reduction of hyperstoichiometric materials to stoichiometry followed by reoxidation was found to be a nearly reversible process. Hyperstoichiometric materials that had been reduced in hydrogen showed approximately the same unit-cell size as did those formed initially at stoichiometry. Oxidation of stoichiometric solid solutions resulted in a shrinkage of unit-cell dimensions to approximately the same as those for air-sintered materials.

Air-sintered solid solutions reduced to stoichiometry and reoxidized in air resulted in a return to approximately the same oxygen-metal atom ratio as before reduction. The greatest apparent difference in the reoxidation of these materials was that the material sintered at high temperatures was more resistant to oxidation. 
Stoichiometric solid solutions formed by hydrogen sintering at lower temperatures oxidized to a higher degree than did the equivalent air-sintered materials. Solid solutions formed by hydrogen sintering at higher temperatures oxidized to approximately the same degree as did air-sintered materials, although oxidation reached a maximum at a lower temperature for the stoichiometric materials. The most noticeable effect due to hydrogen sintering was the increased oxidation resistance of the 70 and $90 \mathrm{~m} / \mathrm{oUO}_{2}$ compositions.

Measurements of dimensional change during the heating of nonstoichiometric solid solutions showed an abnormal expansion and, for high $\mathrm{UO}_{2}$ concentrations, a permanent expansion on the initial heating apparently associated with oxygen loss. Reheating the materials resulted in uniform expansion and no further dimensional change. Stoichiometric materials, heated under the same conditions, had normal expansions during heating, and there were no permanent dimensional changes.

\section{ACKNOWLEDGMENT}

The author wishes to express his appreciation to $\mathrm{Mr}$. J. H. Handwerk for his consultation during this work. The author is deeply indebted to Mr. David R. Lankard for his assistance with the experimental work in this program. 


\section{REFERENCES}

1. Alberman, K. B., and Anderson, J. S., Oxides of Uranium, J. Chem. Soc. (Supplement Issue, No. 2), pp. 5303-5311 (1949).

2. a. Hering, H., and Perio, P., Equilibrium of Uranium Oxides Between $\mathrm{UO}_{2}$ and $\mathrm{U}_{3} \mathrm{O}_{8}$, Bull. Soc. Chim, France, pp. $351-357$ (1952).

b. Perio, P., Considerations on Uranium Oxides Between $\mathrm{UO}_{2}$ and $\mathrm{U}_{3} \mathrm{O}_{8}$, ibid., pp. 840-841 (1953).

3. Gronvold, Fredrik, High Temperature X-Ray Study of Uranium Oxides in the $\mathrm{UO}_{2}-\mathrm{U}_{3} \mathrm{O}_{8}$ Region, J. Inorg. Nucl. Chem. 1(6), 357 (1955).

4. a. Jolibois, P., A New Oxide of Uranium, $\mathrm{U}_{3} \mathrm{O}_{7}$, Compt. Rend. 224, pp. $1395-96(1947)$.

b. Gr onvold, F., and Haraldsen, H., Oxidation of Uranium Dioxide $\left(\mathrm{UO}_{2}\right)$, Nature 162, 69-70 (1948).

5. Hoekstra, H., and Siegel, S., "Recent Developments in Chemistry of the Uranium-Oxygen System," Proc. International Conference on Peaceful Uses of Atomic Energy 7, Geneva (1955), pp. 394-400.

6. Biltz, W., and Muller, H., "The Chemistry of Uranium," Chapter 11, p. 249, National Nuclear Energy Series, Manhattan Project Technicai Section, Division VIII, 5, McGraw-Hill Book Company, Inc., New York (1951).

7. Warde, J., and Johnson, J., Recent Developments in Technology of Ceramic Materials for Nuclear Energy Service, J. Franklin Inst. 260(6), 455-466(1955).

8. a. Gruen, D. M., Valence Stabilization in Crystals, J. Chem. Phys. 21 (11), $2083(1953)$.

b. Gruen, D. M., Absorption Spectra and Electrical Conductivities of $\mathrm{UO}_{2}-\mathrm{ThO}_{2}$ Solid Solutions, J. Am. Chem. Soc. $76(8), 2117$ (1954).

9. Anderson, J., Edgington, D., Roberts, L., and Wait, E., Oxides of Uranium: IV, System $\mathrm{UO}_{2}-\mathrm{ThO}_{2}-\mathrm{O}$, J. Chem. Soc., p. 3324 (1954).

10. Hund, F., and Niessen, G., Anomalous Solid Solution in the System Thorium Oxide-Uranium Oxide, Z. Elektrochem. 56, 972 (1952).

11. Trzebiatowski, W., and Selwood, P., The Magnetic Susceptibility of Urania-Thoria Solid Solutions, J. Am. Chem. Soc. 72(10), 4504 (1950). 
12. Lambertson, W., Mueller, M. H., and Gunzel, F., Uranium Oxide Phase Equilibrium Systems: IV, $\mathrm{UO}_{2}-\mathrm{ThO}_{2}, \mathrm{~J}$. Am. Ceram. Soc. 36(12), 397 (1953).

13. Handwerk, J. H., Abernathy, L., and Bach, R., Thoria and Urania Bodies, Am. Ceram. Soc.Bull. 36(3), 99 (1957).

14. Kolar, D., Lynch, E. D, and Handwerk, J. H., Influence of Gas Flow on DTA Curves of $\mathrm{UO}_{2}, \mathrm{~J}$. Am. Ceram. Soc. 45(3), 141 (1962)。 